\title{
Glycoalkaloids: Structure, Properties, and Interactions with Model Membrane Systems
}

\author{
Bishal Nepal and Keith J. Stine * \\ Department of Chemistry and Biochemistry, University of Missouri-Saint Louis, Saint Louis, MO 63121, USA \\ * Correspondence: kstine@umsl.edu; Tel.: +1-314-516-5346
}

Received: 22 June 2019; Accepted: 31 July 2019; Published: 5 August 2019

check for updates

\begin{abstract}
The glycoalkaloids which are secondary metabolites from plants have proven to be of significant interest for their biological properties both in terms of their roles in plant biology and the effects they exhibit when ingested by humans. The main feature of the action of glycoalkaloids is their strong binding to $3 \beta$-hydroxysterols, such as cholesterol, to form complexes with the consequence that membrane structure is significantly perturbed, and leakage or release of contents inside cells or liposomes becomes possible. The glycoalkaloids have been studied for their ability to inhibit the growth of cancer cells and in other roles such as vaccine adjuvants and as synergistic agents when combined with other therapeutics. The glycoalkaloids have rich and complex physical behavior when interacting with model membranes for which many aspects are yet to be understood. This review introduces the general properties of glycoalkaloids and aspects of their behavior, and then summarizes their effects against model membrane systems. While there are many glycoalkaloids that have been identified, most physical or biological studies have focused on the readily available ones from tomatoes ( $\alpha$-tomatine), potatoes ( $\alpha$-chaconine and $\alpha$-solanine), and eggplant ( $\alpha$-solamargine and $\alpha$-solasonine).
\end{abstract}

Keywords: glycoalkaloid; membrane; monolayer; liposome

\section{Introduction}

A number of classes of compounds are known to disrupt cell membranes by interfering with bilayer structure, including dendrimers [1], chitosan [2], and membrane-active lytic peptides [3]. In this review, the focus is on the disruption of membrane structure by the class of compounds known as glycoalkaloids [4,5] which exert such effects by binding to cholesterol that is ubiquitously present in cell membranes [6], forming complexes that can aggregate and compromise the membrane structure. A particularly unique feature of these compounds is that in addition to their membrane-disrupting effects, they also interact with biological pathways in cells $[7,8]$ and function as inhibitors of cholinesterase enzymes [9,10]. In particular, this review focuses on studies that have involved model membrane systems such as liposomes and monolayers at the water-air interface. Glycoalkaloids have been widely studied for many reasons, including their anti-cancer activities [11,12] either alone or in combination with various therapeutic agents [13-16], and their potential use as vaccine adjuvants [17-19]. Their study remains of major interest given their potential medicinal applications [20]. This review also surveys the biological effects of glycoalkaloids, as the connection between the physical interactions with membranes as studied primarily in model systems such as liposomes and monolayers, and the biological effects as primarily studied in cell lines poses an important question for future research. Glycoalkaloids are readily available natural products that may prove useful in therapeutic applications, alone or in combination with other biologically active agents. 


\section{Origin, Structure, and General Properties of Glycoalkaloids}

\subsection{Origin of Glycoalkaloids}

Plants of the Solanaceae family include tomatoes, potatoes, and eggplants, and are well known to produce secondary metabolites known as glycoalkaloids [21]. The glycoalkaloids are produced in the leaves, flowers, and roots of the plant. In the case of potatoes, they are also found in the sprouts [22]. Tomato plants produce the glycoalkaloid $\alpha$-tomatine, potato plants produce both $\alpha$-chaconine and $\alpha$-solanine, and eggplants produce both $\alpha$-solamargine and $\alpha$-solasonine (see Figure 1 ). Green tomatoes can have up to $500 \mathrm{mg} \mathrm{kg}^{-1}$ of tomatine in the fruit, which will decrease to near $5 \mathrm{mg} \mathrm{kg}^{-1}$ upon ripening [5]. The concentration of tomatine in the vines will stay near $500 \mathrm{mg} \mathrm{kg}^{-1}$. The amount of $\alpha$-tomatine in red tomatoes consumed by humans is $10-30 \mathrm{mg} \mathrm{kg}^{-1}$, but if green tomatoes are consumed then the level will be $200-500 \mathrm{mg} \mathrm{kg}^{-1}$. In eggplants, the average glycoalkaloid concentration for 21 varieties was found to vary from $0.625-20.5 \mathrm{mg} \mathrm{kg}^{-1}$ [23]. The glycoalkaloid content of potatoes varies widely with potato type and conditions of cultivation [24] and will increase in damaged plants [25]. The glycoalkaloid content of normal potato tubers is reported as $12-20 \mathrm{mg} \mathrm{kg}^{-1}$ while green tubers can have $250-280 \mathrm{mg} \mathrm{kg}^{-1}$ and green skin $1500-2200 \mathrm{mg} \mathrm{kg}^{-1}$ [26]. The enzymes involved in the natural synthesis of the oligosaccharides of the glycoalkaloids have been reviewed [27].

\subsection{Structure of Glycoalkaloids}

The glycoalkaloids consist of a nitrogen-containing steroidal aglycone and an attached oligosaccharide. The prefix $\alpha$-refers to the compound with fully intact oligosaccharide, whereas removal of one sugar would be denoted by a $\beta$-prefix, removal of two sugars by a $\gamma$-prefix, and removal of three for a tetrasaccharide by a $\delta$-prefix. The aglycones are referred to as tomatidine, solanidine, and solasidine, respectively. The branched tetrasaccharide of $\alpha$-tomatine is known as lycotetraose. The branched trisaccharide chacotriose constitutes $\alpha$-chaconine when linked to solanidine, and $\alpha$-solamargine when linked to solasidine. The branched trisaccharide solatriose forms $\alpha$-solanine when linked to solanidine and $\alpha$-solasonine when linked to solasidine. The structures of the glycoalkaloids from tomato, potato, and eggplant are shown in Figure 1. The solubility of tomatine in water decreases with $\mathrm{pH}$, being reported as $6 \mathrm{mM}$ at $\mathrm{pH} 5,1 \mathrm{mM}$ at $\mathrm{pH} 6,0.040 \mathrm{mM}$ at $\mathrm{pH} 7$, and $0.030 \mathrm{mM}$ at $\mathrm{pH} 8$ [28].

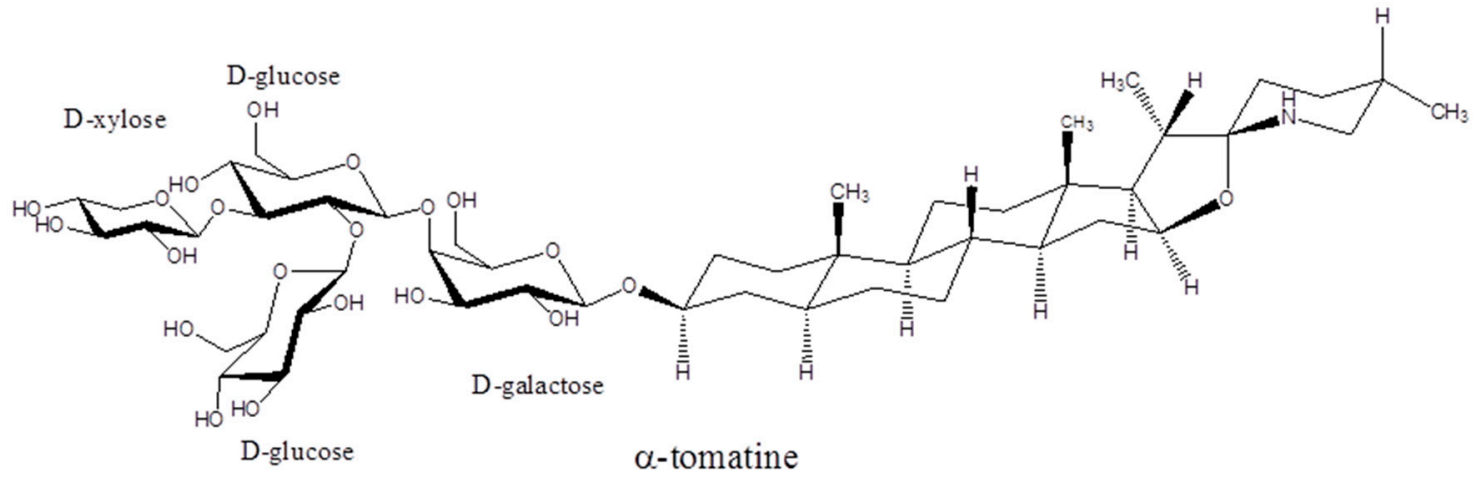

Figure 1. Cont. 


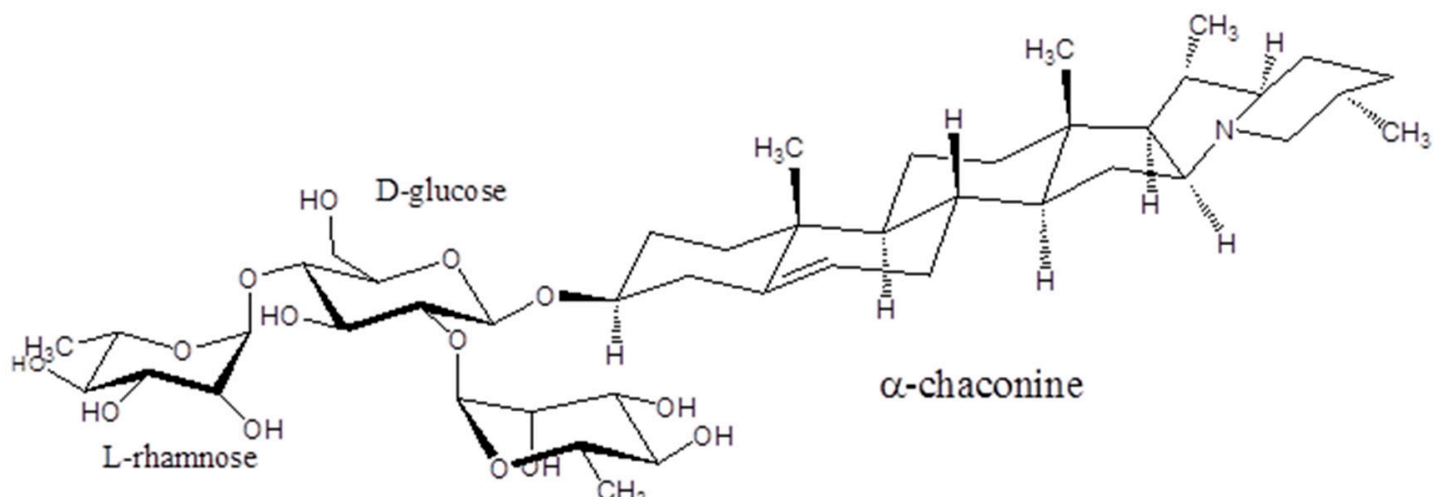

\section{L-rhamnose}



L-rhamnose



L-rhamnose

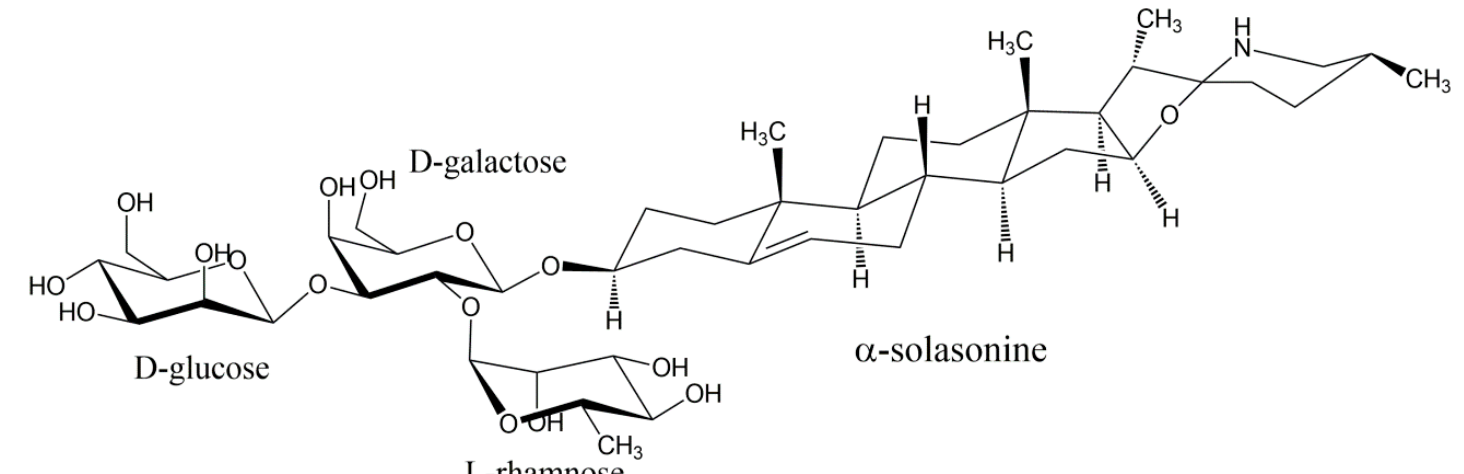

Figure 1. Structures of the glycoalkaloids $\alpha$-tomatine, $\alpha$-chaconine, $\alpha$-chaconine, $\alpha$-solamargine, and $\alpha$-solasonine.

\subsection{General Properties of Glycoalkaloids}

These compounds are important for the defense of the plant against pests and pathogens $[29,30]$ and have numerous biological and medicinal effects if ingested by humans [31]. While $\alpha$-tomatine 
can help to protect the tomato plant against fungal pathogens and inhibit fungal growth [32], a number of pathogens express an enzyme that can detoxify tomatine by hydrolysis of sugars [33]. For example, fungi can resist these compounds by acidifying their environment or expressing enzymes that cleave sugar units off of the oligosaccharide [34]. Glycoalkaloids have been found to inhibit feeding by snails [35], and by a variety of insects [36]. It has been found that the effects of $\alpha$-tomatine, and glycoalkaloids in general, require the presence of the intact oligosaccharide unit [37]. Glycoalkaloids have toxicity to humans, through both their membrane disrupting activity and also their activity as inhibitors of acetylcholinesterase [38]. Symptoms of excessive glycoalkaloid intake range from intestinal discomfort to neurological problems and for higher amounts, low blood pressure, rapid pulse, coma, or death [39]. A toxic glycoalkaloid dose is $2-5 \mathrm{mg} \mathrm{kg}^{-1}$ bodyweight. The glycoalkaloids produced in pairs such as $\alpha$-chaconine and $\alpha$-solanine are known to exhibit synergism in their effects such as membrane disruption [40-42]. The synergistic effects are highly interesting as the combination of the two compounds exerts a much greater effect than the average of the effect of either compound applied alone at the same total concentrations.

Glycoalkaloids form 1:1 complexes with cholesterol, the stoichiometry having been confirmed by precipitation experiments [43]. Glycoalkaloids form insoluble complexes with sterols in $96 \%$ ethanol. The intact oligosaccharide is required, and removal of one or more sugars reduces their ability to bind sterols. Glycoalkaloids also form complexes with other $3 \beta$-hydroxy sterols. The formation of complexes between tomatine and cholesterol results in morphological features such as protrusions and ridges that can be used to image the presence of un-esterified cholesterol in cells and tissues using freeze-fracture scanning electron microscopy [44,45]. Other related agents used for imaging cholesterol in cells by cholesterol complexation include digitonin [46], which is a saponin, and filipin, a polyene antibiotic [47]. Tomatine has hemolytic activity against red blood cells [48].

\subsection{Anti-Cancer Properties of Glycoalkaloids}

Glycoalkaloids have been explored for their observed cytotoxic activity against certain cancer cell lines and a summary of some of the dose levels and cellular effects are reported is shown in Table 1. Some studies focus only on reporting the effect of the glycoalkaloid on cellular viability or proliferation while other studies apply cellular assays aimed at assessing the biochemical mechanisms of cytotoxicity. Many studies use pure glycoalkaloids but some studies work with extracts and are thus less precise due to the possible effects of minor components. In addition to membrane disrupting effects, glycoalkaloids also act against cancer cells by promoting apoptosis [49], causing cell cycle arrest with an accumulation of cells in the G1 phase [50], and inhibiting cell signaling pathways [51], all of which indicates that they interact with specific cellular receptors. Tomatine extracts from green tomatoes were found to be much more cytotoxic against cancer cell lines due to their higher levels of tomatine. $\mathrm{IC}_{50}$ values were found to be the lowest against AGS (gastric cancer) and HT-27 colon cancer cell lines at $0.03 \mu \mathrm{gL} \mathrm{m}^{-1}$ [52]. Dehydrotomatine, a minor component from tomato plants with a single double bond in the steroidal $\mathrm{B}$ ring, was much less active with $\mathrm{IC}_{50}$ values of $578 \mu \mathrm{g} \mathrm{mL} \mathrm{m}^{-1}$ and $262 \mu \mathrm{g} \mathrm{mL} \mathrm{L}^{-1}$ against AGS and HT-27 cells, respectively. Tomatidenol and tomatidine, the aglycones of dehydrotomatine and tomatine, showed limited activity against the cancer cell lines. It was proposed that the cytotoxicity was primarily due to membrane disruption through cholesterol complexation. The health effects of glycoalkaloids in the human food chain have been reviewed [53]. Combination of sub-toxic concentrations of tomatine with paclitaxel showed synergistic effects in cytotoxicity against androgen-independent prostate cancer (PC-3) cells [13]. The percentage of cells in early-stage apoptosis was $50.23 \pm 9.86 \%$ for the combination of $1 \mu \mathrm{M}$ $\alpha$-tomatine and $5 \mathrm{nM}$ paclitaxel as compared to $5.23 \pm 2.51 \%$ for $1 \mu \mathrm{M} \alpha$-tomatine and $13.38 \pm 3.22 \%$ for $5 \mathrm{nM}$ paclitaxel alone. Acid hydrolysis of the lycotetraose unit of tomatine to produce products with zero (aglycone), one, two, or three remaining sugars was carried out and the cytotoxicity of these derivatives tested against breast, gastric, and prostate cancer cell lines [54]. Removal of just one sugar to produce $\beta_{1}$-tomatine resulted in an increase in the $\mathrm{IC}_{50}$ against prostate cancer (PC-3) cells from $3.0 \mu \mathrm{g} \mathrm{mL} \mathrm{m}^{-1}$ to $82.5 \mu \mathrm{g} \mathrm{mL}-1$ and further removal of sugar units further increased the value of $\mathrm{IC}_{50}$. 
The increase of the $\mathrm{IC}_{50}$ values, as sugar is removed from $\alpha$-tomatine to give the series of hydrolysis products and then the aglycone, is dramatic and is shown in Figure 2. The compounds are seen to exhibit a similar pattern of cytotoxicity against normal human liver cells (Chang), and normal human lung cells (HeI299) as they do against the cancer cell lines.

Table 1. Selection of reported data for effect of glycoalkaloids against cancer cells lines, noting doses and specific cellular effects (if reported). Data reported in concentration units (such as $\mu \mathrm{M}$ ) are converted to $\mu \mathrm{g} \mathrm{mL} \mathrm{m}^{-1}$. Data is not shown for extracts.

\begin{tabular}{|c|c|c|c|c|}
\hline Glycoalkaloid & Cell Type & Dosage $\left(\mathrm{g} \mathrm{mL}^{-1}\right)$ & Outcome & Ref \\
\hline$\alpha$-chaconine & $\begin{array}{l}\text { HT-29 human } \\
\text { colon carcinoma }\end{array}$ & 5.0 & $\begin{array}{l}\text { Apoptosis, ERK inhibition, } \\
\text { caspase- } 3 \text { activation }\end{array}$ & [49] \\
\hline$\alpha$-chaconine & HepG2 liver cancer & 10 & $\begin{array}{l}94.9 \% \text { reduction in MTT activity } \\
\text { after } 48 \mathrm{~h}\end{array}$ & [55] \\
\hline$\alpha$-chaconine & AGS gastric cancer & 10 & $\begin{array}{l}89.7 \% \text { reduction in MTT activity } \\
\text { after } 48 \mathrm{~h}\end{array}$ & [55] \\
\hline$\alpha$-chaconine & PC-6 lung cancer & Not stated & $\begin{array}{l}\text { Growth inhibition of } 50 \% \text { at } 72 \mathrm{~h} \\
\quad\left(\mathrm{GI}_{50}\right)=1.83 \mu \mathrm{g} \mathrm{mL}^{-1}\end{array}$ & [56] \\
\hline$\alpha$-chaconine & $\begin{array}{l}\text { MCF-7 breast } \\
\text { cancer }\end{array}$ & Not stated & $\begin{array}{l}\text { Growth inhibition of } 50 \% \text { at } 72 \mathrm{~h} \\
\qquad\left(\mathrm{GI}_{50}\right)=1.54 \mu \mathrm{g} \mathrm{mL}^{-1}\end{array}$ & [56] \\
\hline$\alpha$-chaconine & $\begin{array}{l}\text { NUGC-3 stomach } \\
\text { cancer }\end{array}$ & Not stated & $\begin{array}{l}\text { Growth inhibition of } 50 \% \text { at } 72 \mathrm{~h} \\
\quad\left(\mathrm{GI}_{50}\right)=1.43 \mu \mathrm{g} \mathrm{mL}\end{array}$ & [56] \\
\hline$\alpha$-chaconine & $\begin{array}{l}\text { SW620 colon } \\
\text { cancer }\end{array}$ & Not stated & $\begin{array}{l}\text { Growth inhibition of } 50 \% \text { at } 72 \mathrm{~h} \\
\quad\left(\mathrm{GI}_{50}\right)=1.46 \mu \mathrm{g} \mathrm{mL}^{-1}\end{array}$ & [56] \\
\hline $\begin{array}{c}\alpha \text {-chaconine }+ \\
\alpha \text {-solanine }\end{array}$ & HepG2 liver cancer & $\begin{array}{l}\text { Combinations that } \\
\text { add to } 10(5+5,3+ \\
7,7+3,1+9,9+1)\end{array}$ & $\begin{array}{c}9+1 \text { combination is synergistic } \\
(94.7 \% \text { reduction in MTT activity) } \\
\text { others are antagonistic }\end{array}$ & [57] \\
\hline $\begin{array}{c}\alpha \text {-chaconine }+ \\
\alpha \text {-solanine }\end{array}$ & AGS gastric cancer & $\begin{array}{l}\text { Combinations that } \\
\text { add to } 10(5+5,3+ \\
7,7+3,1+9,9+1)\end{array}$ & $\begin{array}{c}\text { All combinations are synergistic, } \\
87.6-89.0 \% \text { reduction in MTT } \\
\text { activity }\end{array}$ & [58] \\
\hline $\begin{array}{l}\alpha \text {-chaconine and } \\
\text { hydrolysis } \\
\text { products }\end{array}$ & $\begin{array}{l}\text { HT29 colon cancer } \\
\text { cells }\end{array}$ & $0.1,0.5,1,5,10,100$ & $\begin{array}{c}\text { Growth inhibition by MTT assay } \\
=77.3 \% \text { for } \alpha \text {-chaconine, } 48.5 \% \\
\text { for } \beta_{1} \text {-chaconine, } 53.6 \% \text { for } \\
\beta_{2} \text {-chaconine, } 12.8 \% \text { for } \\
\gamma \text {-chaconine, and } 32.5 \% \text { for } \\
\text { solanidine (aglycone). ( } 4 \mathrm{~h}, 10 \mu \mathrm{g} \\
\mathrm{mL}^{-1}, \text { data also reported for } 24 \mathrm{~h} \text {, } \\
48 \mathrm{~h} \text { and other concentrations) }\end{array}$ & [58] \\
\hline $\begin{array}{l}\alpha \text {-chaconine and } \\
\text { hydrolysis } \\
\text { products }\end{array}$ & $\begin{array}{l}\text { HepG2 liver cancer } \\
\text { cells }\end{array}$ & $0.1,0.5,1,5,10,100$ & $\begin{array}{c}\text { Growth inhibition by MTT assay } \\
=83.3 \% \text { for } \alpha \text {-chaconine, } 44.0 \% \\
\text { for } \beta_{1} \text {-chaconine, } 37.8 \% \text { for } \\
\beta_{2} \text {-chaconine, } 76.3 \% \text { for } \\
\gamma \text {-chaconine, and } 71.5 \% \text { for } \\
\text { solanidine (aglycone). ( } 4 \mathrm{~h}, 10 \mu \mathrm{g} \\
\mathrm{mL}^{-1}, \text { data also reported for } 24 \mathrm{~h} \text {, } \\
48 \mathrm{~h} \text { and other concentrations) }\end{array}$ & [58] \\
\hline$\alpha$-solamargine & $\begin{array}{l}\text { HT29 colon cancer } \\
\text { cells }\end{array}$ & $0.1,0.5,1,5,10,100$ & $\begin{array}{l}\text { Growth inhibition by MTT assay } \\
=71.8 \%(4 \mathrm{~h}, 10 \mu \mathrm{g} \mathrm{mL}-1, \text { data } \\
\text { also reported for } 24 \mathrm{~h}, 48 \mathrm{~h} \text { and } \\
\text { other concentrations })\end{array}$ & [58] \\
\hline$\alpha$-solamargine & $\begin{array}{l}\text { HepG2 liver cancer } \\
\text { cells }\end{array}$ & $0.1,0.5,1,5,10,100$ & $\begin{array}{l}\text { Growth inhibition by MTT assay } \\
=81.4 \%(4 \mathrm{~h}, 10 \mu \mathrm{g} \mathrm{mL}-1 \text {, data } \\
\text { also reported for } 24 \mathrm{~h}, 48 \mathrm{~h} \text { and } \\
\text { other concentrations })\end{array}$ & [55] \\
\hline
\end{tabular}


Table 1. Cont.

\begin{tabular}{|c|c|c|c|c|}
\hline Glycoalkaloid & Cell Type & Dosage $\left(\mathrm{g} \mathrm{mL}^{-1}\right)$ & Outcome & Ref \\
\hline$\alpha$-solamargine & PC-6 lung cancer & Not stated & $\begin{array}{l}\text { Growth inhibition of } 50 \% \text { at } 72 \mathrm{~h}\left(\mathrm{GI}_{50}\right)=2.66 \\
\mu \mathrm{g} \mathrm{mL} \mathrm{mL}^{-1}\end{array}$ & [56] \\
\hline$\alpha$-solamargine & $\begin{array}{l}\text { MCF-7 breast } \\
\text { cancer }\end{array}$ & Not stated & $\begin{array}{l}\text { Growth inhibition of } 50 \% \text { at } 72 \mathrm{~h}\left(\mathrm{GI}_{50}\right)=2.16 \\
\qquad \mu \mathrm{g} \mathrm{mL}^{-1}\end{array}$ & [56] \\
\hline$\alpha$-solamargine & $\begin{array}{l}\text { NUGC-3 stomach } \\
\text { cancer }\end{array}$ & Not stated & $\begin{array}{l}\text { Growth inhibition of } 50 \% \text { at } 72 \mathrm{~h}\left(\mathrm{GI}_{50}\right)=1.95 \\
\qquad \mathrm{~g} \mathrm{~mL}^{-1}\end{array}$ & [56] \\
\hline$\alpha$-solamargine & $\begin{array}{l}\text { SW620 colon } \\
\text { cancer }\end{array}$ & Not stated & $\begin{array}{l}\text { Growth inhibition of } 50 \% \text { at } 72 \mathrm{~h}\left(\mathrm{GI}_{50}\right)=1.62 \\
\mu \mathrm{g} \mathrm{mL} \mathrm{mL}^{-1}\end{array}$ & [56] \\
\hline$\alpha$-solamargine & $\begin{array}{l}\text { HeLa cervical } \\
\text { cancer }\end{array}$ & Not stated & $\mathrm{IC}_{50}(\mathrm{MTT}$ assay $)=6.0 \mu \mathrm{g} \mathrm{mL}^{-1}$ & [59] \\
\hline$\alpha$-solamargine & A549 lung cancer & Not stated & $\mathrm{IC}_{50}(\mathrm{MTT}$ assay $)=8.0 \mu \mathrm{g} \mathrm{mL}^{-1}$ & [59] \\
\hline$\alpha$-solamargine & $\begin{array}{l}\text { MCF-7 breast } \\
\text { cancer }\end{array}$ & Not stated & $\mathrm{IC}_{50}(\mathrm{MTT}$ assay $)=2.1 \mu \mathrm{g} \mathrm{mL}^{-1}$ & [59] \\
\hline$\alpha$-solamargine & $\begin{array}{l}\text { K562 chronic } \\
\text { myelogenous } \\
\text { leukemia }\end{array}$ & Not stated & $\mathrm{IC}_{50}(\mathrm{MTT}$ assay $)=5.2 \mu \mathrm{g} \mathrm{mL}^{-1}$ & [59] \\
\hline$\alpha$-solamargine & $\begin{array}{l}\text { HCT116 colon } \\
\text { cancer }\end{array}$ & Not stated & $\mathrm{IC}_{50}(\mathrm{MTT}$ assay $)=3.8 \mu \mathrm{g} \mathrm{mL}^{-1}$ & [59] \\
\hline$\alpha$-solamargine & U87 glioblastoma & Not stated & $\mathrm{IC}_{50}(\mathrm{MTT}$ assay $)=3.2 \mu \mathrm{g} \mathrm{mL}^{-1}$ & [59] \\
\hline$\alpha$-solamargine & HepG2 liver cancer & Not stated & $\mathrm{IC}_{50}(\mathrm{MTT}$ assay $)=2.5 \mu \mathrm{g} \mathrm{mL}^{-1}$ & [59] \\
\hline$\alpha$-solamargine & $\begin{array}{l}\text { H661 large cell } \\
\text { lung cancer }\end{array}$ & $0-10.4$ & $\begin{array}{l}\mathrm{ED}_{50}\left(\left[{ }^{3} \mathrm{H}\right] \text { thymidine DNA incorporation }\right. \\
\text { assay at } 18 \mathrm{~h})=3.11 \mu \mathrm{g} \mathrm{mL} \mathrm{L}^{-1}, \text { increase in } \\
\text { HER2 expression, evidence for apoptosis } \\
\text { including chromatin condensation, DNA } \\
\text { fragmentation and cell morphology changes }\end{array}$ & [14] \\
\hline$\alpha$-solamargine & $\begin{array}{l}\text { H69 small cell lung } \\
\text { cancer }\end{array}$ & $0-10.4$ & $\begin{array}{l}\mathrm{ED}_{50}\left(\left[{ }^{3} \mathrm{H}\right] \text { thymidine DNA incorporation }\right. \\
\text { assay at } 18 \mathrm{~h})=5.02 \mu \mathrm{g} \mathrm{mL} \mathrm{L}^{-1} \text {, increase in } \\
\text { HER2 expression, evidence for apoptosis } \\
\text { including chromatin condensation, DNA } \\
\text { fragmentation and cell morphology changes }\end{array}$ & [14] \\
\hline$\alpha$-solamargine & $\begin{array}{l}\text { HBL-100 breast } \\
\text { cancer cells }\end{array}$ & $0-217$ & $\begin{array}{c}\mathrm{IC}_{50} \text { (MTS cell viability assay at } 16 \mathrm{~h} \text { ) }=1.80 \\
\mu \mathrm{g} \mathrm{mL} \mathrm{m}^{-1}, \text { evidence for apoptosis, } \\
\text { upregulated TNFR-I, Fas, and TRADD, } \\
\text { upregulate Bax and downregulate Bcl-2 and } \\
\text { Bcl-xL, chromatin condensation, blebbing, } \\
\text { and shrinkage }\end{array}$ & [16] \\
\hline$\alpha$-solamargine & $\begin{array}{l}\text { ZR-75-1 breast } \\
\text { cancer cells }\end{array}$ & $0-217$ & $\begin{array}{l}\mathrm{IC}_{50}(\mathrm{MTS} \text { cell viability assay at } 16 \mathrm{~h})=2.60 \\
\mu \mathrm{g} \mathrm{mL}-1 \text {, same as for HBL-100 cells }\end{array}$ & [16] \\
\hline$\alpha$-solamargine & $\begin{array}{l}\text { SK-BR-3 breast } \\
\text { cancer cells }\end{array}$ & $0-217$ & $\begin{array}{c}\mathrm{IC}_{50}(\mathrm{MTS} \text { cell viability assay at } 16 \mathrm{~h})=1.87 \\
\mu \mathrm{g} \mathrm{mL}{ }^{-1}, \text { same as for HBL-100 cells }\end{array}$ & [16] \\
\hline$\alpha$-solamargine & $\begin{array}{l}\text { Bcap-37 human } \\
\text { breast cancer }\end{array}$ & $0-8.84$ & $\begin{array}{l}\mathrm{IC}_{50}(\mathrm{MTT} \text { assay after } 24 \mathrm{~h})=5.61 \mu \mathrm{g} \mathrm{mL}^{-1} \\
\text { evidence for apoptosis similar but stronger as } \\
\text { for } \alpha \text {-solasonine }\end{array}$ & [60] \\
\hline$\alpha$-solamargine & $\begin{array}{l}\text { MCF-7 human } \\
\text { breast cancer }\end{array}$ & $0-8.84$ & $\mathrm{IC}_{50}(\mathrm{MTT}$ assay after $24 \mathrm{~h})=1.14 \mu \mathrm{g} \mathrm{mL}^{-1}$ & [60] \\
\hline$\alpha$-solamargine & $\begin{array}{l}\text { A-431 epidermoid } \\
\text { carcinoma }\end{array}$ & $0-8.84$ & $\mathrm{IC}_{50}(\mathrm{MTT}$ assay after $24 \mathrm{~h})=8.27 \mu \mathrm{g} \mathrm{mL}^{-1}$ & [60] \\
\hline$\alpha$-solanine & HepG2 liver cancer & 10 & $86.6 \%$ reduction in MTT activity after $48 \mathrm{~h}$ & [55] \\
\hline$\alpha$-solanine & AGS gastric cancer & 10 & $79.0 \%$ reduction in MTT activity after $48 \mathrm{~h}$ & [55] \\
\hline$\alpha$-solanine & PC-6 lung cancer & Not stated & $\begin{array}{l}\text { Growth inhibition of } 50 \% \text { at } 72 \mathrm{~h}\left(\mathrm{GI}_{50}\right)= \\
15.70 \mu \mathrm{g} \mathrm{mL}^{-1}\end{array}$ & [56] \\
\hline
\end{tabular}


Table 1. Cont.

\begin{tabular}{|c|c|c|c|c|}
\hline Glycoalkaloid & Cell Type & Dosage $\left(\mathrm{g} \mathrm{mL}^{-1}\right)$ & Outcome & Ref \\
\hline $\begin{array}{l}\alpha \text {-solanine and } \\
\text { hydrolysis } \\
\text { products }\end{array}$ & $\begin{array}{l}\text { HT29 colon cancer } \\
\text { cells }\end{array}$ & $\begin{array}{l}0.1,0.5,1,5,10 \\
100\end{array}$ & $\begin{array}{l}\text { Growth inhibition by MTT assay }=81.7 \% \text { for } \\
\alpha \text {-solanine, } 51.4 \% \text { for } \beta_{2} \text {-solanine, } 55.0 \% \text { for } \\
\text { solasodine (aglycone). }\left(4 \mathrm{~h}, 10 \mu \mathrm{g} \mathrm{mL} \mathrm{m}^{-1} \text {, data }\right. \\
\text { also reported for } 24 \mathrm{~h}, 48 \mathrm{~h} \text { and other } \\
\text { concentrations) }\end{array}$ & [58] \\
\hline $\begin{array}{l}\alpha \text {-solanine and } \\
\text { hydrolysis } \\
\text { products }\end{array}$ & $\begin{array}{l}\text { HepG2 liver cancer } \\
\text { cells }\end{array}$ & $\begin{array}{l}0.1,0.5,1,5,10 \\
100\end{array}$ & $\begin{array}{c}\text { Growth inhibition by MTT assay }=80.9 \% \text { for } \\
\alpha \text {-solanine, } 13.3 \% \text { for } \beta_{2} \text {-solanine, } 78.3 \% \text { for } \\
\text { solasodine (aglycone). }\left(4 \mathrm{~h}, 10 \mu \mathrm{g} \mathrm{mL} \mathrm{m}^{-1} \text {, data }\right. \\
\text { also reported for } 24 \mathrm{~h}, 48 \mathrm{~h} \text { and other } \\
\text { concentrations) }\end{array}$ & [58] \\
\hline$\alpha$-solasonine & PC-6 lung cancer & Not stated & $\begin{array}{l}\text { Growth inhibition of } 50 \% \text { at } 72 \mathrm{~h}\left(\mathrm{GI}_{50}\right)=14.4 \\
\mu \mathrm{g} \mathrm{mL} \mathrm{mL}^{-1}\end{array}$ & [56] \\
\hline$\alpha$-solasonine & $\begin{array}{l}\text { MCF-7 breast } \\
\text { cancer }\end{array}$ & Not stated & $\begin{array}{l}\text { Growth inhibition of } 50 \% \text { at } 72 \mathrm{~h}\left(\mathrm{GI}_{50}\right)=9.70 \\
\mu \mathrm{g} \mathrm{mL} \mathrm{mL}^{-1}\end{array}$ & [56] \\
\hline$\alpha$-solasonine & $\begin{array}{l}\text { NUGC-3 stomach } \\
\text { cancer }\end{array}$ & Not stated & $\begin{array}{l}\text { Growth inhibition of } 50 \% \text { at } 72 \mathrm{~h}\left(\mathrm{GI}_{50}\right)= \\
12.10 \mu \mathrm{gL}^{-1}\end{array}$ & [56] \\
\hline$\alpha$-solasonine & $\begin{array}{l}\text { SW620 colon } \\
\text { cancer }\end{array}$ & Not stated & $\begin{array}{c}\text { Growth inhibition of } 50 \% \text { at } 72 \mathrm{~h}\left(\mathrm{GI}_{50}\right)=6.72 \\
\mu \mathrm{g} \mathrm{mL}\end{array}$ & [56] \\
\hline$\alpha$-solasonine & $\begin{array}{l}\text { Bcap-37 human } \\
\text { breast cancer }\end{array}$ & $0-17.36$ & $\begin{array}{c}\mathrm{IC}_{50}(\mathrm{MTT} \text { assay after } 24 \mathrm{~h})=19.64 \mu \mathrm{g} \mathrm{mL}^{-1}, \\
\text { evidence for apoptosis, mitochondrial } \\
\text { dysfunction and cytochrome } c \text { release, } \\
\text { caspase-3 activity, Annexin } \mathrm{V} \text { positive } \\
\text { staining, downregulated BCl-2 and Bcl-xL } \\
\text { and upregulated Bax }\end{array}$ & [60] \\
\hline$\alpha$-solasonine & $\begin{array}{l}\text { MCF-7 human } \\
\text { breast cancer }\end{array}$ & $0-17.36$ & $\mathrm{IC}_{50}(\mathrm{MTT}$ assay after $24 \mathrm{~h})=11.70 \mu \mathrm{g} \mathrm{mL}^{-1}$ & [60] \\
\hline$\alpha$-solasonine & $\begin{array}{l}\text { A-431 epidermoid } \\
\text { carcinoma }\end{array}$ & $0-17.36$ & $\mathrm{IC}_{50}(\mathrm{MTT}$ assay after $24 \mathrm{~h})=15.67 \mu \mathrm{g} \mathrm{mL}^{-1}$ & [60] \\
\hline $\begin{array}{l}\alpha \text {-solasonine and } \\
\text { aglycone }\end{array}$ & $\begin{array}{l}\text { HT29 colon cancer } \\
\text { cells }\end{array}$ & $\begin{array}{l}0.1,0.5,1,5,10 \\
100\end{array}$ & $\begin{array}{l}\text { Growth inhibition by MTT assay }=68.4 \% \text {, } \\
55 \% \text { for solasodine (aglycone). ( } 4 \mathrm{~h}, 10 \mu \mathrm{g} \\
\mathrm{mL}^{-1} \text {, data also reported for } 24 \mathrm{~h}, 48 \mathrm{~h} \text { and } \\
\text { other concentrations) }\end{array}$ & [58] \\
\hline $\begin{array}{l}\alpha \text {-solasonine and } \\
\text { aglycone }\end{array}$ & $\begin{array}{l}\text { HepG2 liver cancer } \\
\text { cells }\end{array}$ & $\begin{array}{l}0.1,0.5,1,5,10 \\
100\end{array}$ & $\begin{array}{l}\text { Growth inhibition by MTT assay }=79.3 \% \text {. } \\
78.3 \% \text { for solasodine (aglycone). ( } 4 \mathrm{~h}, 10 \mu \mathrm{g} \\
\mathrm{mL}^{-1} \text {, data also reported for } 24 \mathrm{~h}, 48 \mathrm{~h} \text { and } \\
\text { other concentrations) }\end{array}$ & [58] \\
\hline$\alpha$-tomatine & $\begin{array}{l}\text { MOLT-4 human } \\
\text { T-lymphoblastic } \\
\text { leukemia }\end{array}$ & $1.03-4.12$ & $\begin{array}{l}\text { Caspase independent cell death, increase p53, } \\
\text { increase in PUMA protein, increase } \\
\text { p21 WAFI/CIPI, activation of Chk2, cell cycle } \\
\text { arrest in G1 phase, no change in viability at } \\
1.03 \mu \mathrm{g} \mathrm{mL} \mathrm{m}^{-1} \text { but } 12 \% \text { cell viability after } 24 \mathrm{~h} \\
\text { for } 4.12 \mu \mathrm{g} \mathrm{mL} \mathrm{mL}^{-1}\end{array}$ & [50] \\
\hline$\alpha$-tomatine & $\begin{array}{l}\text { NCI-H460 (human } \\
\text { lung large cell } \\
\text { carcinoma) }\end{array}$ & up to 4.12 & $\begin{array}{l}\text { Cytotoxic above } 1.55 \mu \mathrm{g} \mathrm{mL} \mathrm{L}^{-1} \text {, reduce } \\
\text { mitochondrial membrane potential, reduce } \\
\text { GSH, increase reactive oxygen species, } \\
\text { change in cell morphology to elongated, } \\
\text { spindle, or shrunken, inactivate PI3K/Akt } \\
\text { signaling, enhancing IkB } \alpha \text { protein expression, } \\
\text { reduce NF-KB DNA-binding activity, } \\
\text { downregulate MMP-7, interfere with the } \\
\text { rearrangement of the actin cytoskeleton, } \\
\text { decrease expression of-FAK, inhibit cell } \\
\text { invasion and migration. }\end{array}$ & [51] \\
\hline
\end{tabular}


Table 1. Cont

\begin{tabular}{|c|c|c|c|c|}
\hline Glycoalkaloid & Cell Type & Dosage $\left(\mathrm{g} \mathrm{mL}^{-1}\right)$ & Outcome & Ref \\
\hline$\alpha$-tomatine & $\begin{array}{l}\text { AGS stomach } \\
\text { cancer }\end{array}$ & $10.34-51.7$ & $\mathrm{IC}_{50}=0.03 \mu \mathrm{g} \mathrm{mL}-1$ by MTT assay after $48 \mathrm{~h}$ & [52] \\
\hline$\alpha$-tomatine & HepG2 liver cancer & $10.34-51.7$ & $\mathrm{IC}_{50}=43 \mu \mathrm{g} \mathrm{mL}{ }^{-1}$ by MTT assay after $48 \mathrm{~h}$ & [52] \\
\hline$\alpha$-tomatine & Ht-29 colon cancer & $10.34-51.7$ & $\mathrm{IC}_{50}=0.03 \mu \mathrm{g} \mathrm{mL}{ }^{-1}$ by MTT assay after $48 \mathrm{~h}$ & [52] \\
\hline$\alpha$-tomatine & $\begin{array}{l}\text { MCF-7 breast } \\
\text { cancer }\end{array}$ & $10.34-51.7$ & $\mathrm{IC}_{50}=5.07 \mu \mathrm{g} \mathrm{mL}^{-1}$ by MTT assay after $48 \mathrm{~h}$ & [52] \\
\hline$\alpha$-tomatine & $\begin{array}{l}\text { LNCaP prostate } \\
\text { cancer cells }\end{array}$ & $0.52-4.12$ & $\mathrm{EC}_{50}=2.74 \pm 0.01 \mu \mathrm{g} \mathrm{mL}^{-1}$ for $24 \mathrm{~h}$ treatment & [52] \\
\hline$\alpha$-tomatine & $\begin{array}{l}\text { MCF-7 human } \\
\text { breast cancer }\end{array}$ & $1.034-9.306$ & $\begin{array}{l}\text { EC50 = 7.41 }(72 \mathrm{~h}) \text {, no DNA damage, loss of } \\
\text { ATP, microscopy shows the collapse of some } \\
\text { cells, TEM shows sign of rapid necrosis }\end{array}$ & [55] \\
\hline$\alpha$-tomatine & $\begin{array}{l}\text { PC-3 prostate } \\
\text { cancer }\end{array}$ & $0.17-5.17$ & $\begin{array}{l}\mathrm{EC}_{50}(\mathrm{MTT} \text { assay after } 24 \mathrm{~h})=1.73 \mu \mathrm{g} \mathrm{mL}^{-1} \text {. } \\
\text { Evidence for apoptosis, Annexin V staining is } \\
\text { positive, decrease in mitochondrial } \\
\text { membrane potential, caspase- }-3,-8 \text {, and }-9 \\
\text { activity, nF-kB activation inhibited, nuclear } \\
\text { condensation }\end{array}$ & [61] \\
\hline $\begin{array}{l}\alpha \text {-tomatine and } \\
\text { hydrolysis } \\
\text { products }\end{array}$ & $\begin{array}{l}\text { MDA-MB-231 } \\
\text { breast cancer }\end{array}$ & $1,10,50,100$ & $\begin{array}{l}\mathrm{IC}_{50}=26.4 \pm 3.6 \text { for } \alpha \text {-tomatine, } 82.3 \pm 11.0 \\
\text { for } \beta_{1} \text {-tomatine, } 137.8 \pm 16.6 \text { for } \gamma \text {-tomatine, } \\
84.5 \pm 6.6 \text { for } \delta \text {-tomatine, and } 336.5 \pm 7.9 \text { for } \\
\text { tomatidine }\left(\text { all in } \mu \mathrm{gL}^{-1}, \text { all } 48 \mathrm{~h}\right)\end{array}$ & [54] \\
\hline $\begin{array}{l}\alpha \text {-tomatine and } \\
\text { hydrolysis } \\
\text { products }\end{array}$ & $\begin{array}{l}\text { KATO-III gastric } \\
\text { cancer }\end{array}$ & $1,10,50,100$ & $\begin{array}{c}\mathrm{IC}_{50}=16.4 \pm 10.0 \text { for } \alpha \text {-tomatine, } 77.1 \pm 13.3 \\
\text { for } \beta_{1} \text {-tomatine, } 156.0 \pm 8.4 \text { for } \gamma \text {-tomatine, } \\
150.4 \pm 11.3 \text { for } \delta \text {-tomatine, and } 623.0 \pm 7.9 \\
\text { for tomatidine (all in } \mu \mathrm{g} \mathrm{mL}-1, \text { all } 48 \mathrm{~h})\end{array}$ & [54] \\
\hline $\begin{array}{l}\alpha \text {-tomatine and } \\
\text { hydrolysis } \\
\text { products }\end{array}$ & $\begin{array}{l}\text { HT29 colon cancer } \\
\text { cells }\end{array}$ & $\begin{array}{c}0.1,0.5,1,5,10 \\
100\end{array}$ & $\begin{array}{c}\text { Growth inhibition by MTT assay }=71.6 \% \text { for } \\
\alpha \text {-tomatine, } 51.3 \% \text { for } \beta_{1} \text {-tomatine, } 17.5 \% \text { for } \\
\gamma \text {-tomatine, } 26.3 \% \text { for } \delta \text {-tomatine and } 11.4 \% \\
\text { for tomatidine (aglycone). }\left(4 \mathrm{~h}, 10 \mu \mathrm{g} \mathrm{mL} \mathrm{L}^{-1}\right. \\
\text { data also reported for } 24 \mathrm{~h}, 48 \mathrm{~h} \text { and other } \\
\text { concentrations) }\end{array}$ & [58] \\
\hline $\begin{array}{l}\alpha \text {-tomatine and } \\
\text { hydrolysis } \\
\text { products }\end{array}$ & $\begin{array}{l}\text { HepG2 liver cancer } \\
\text { cells }\end{array}$ & $\begin{array}{c}0.1,0.5,1,5,10 \\
100\end{array}$ & $\begin{array}{c}\text { Growth inhibition by MTT assay }=85.5 \% \text { for } \\
\alpha \text {-tomatine, } 80.9 \% \text { for } \beta_{1} \text {-tomatine, } 17.8 \% \text { for } \\
\gamma \text {-tomatine, } 52.8 \% \text { for } \delta \text {-tomatine and } 28.8 \% \\
\text { for tomatidine (aglycone). }\left(4 \mathrm{~h}, 10 \mu \mathrm{g} \mathrm{mL} \mathrm{L}^{-1} \text {, }\right. \\
\text { data also reported for } 24 \mathrm{~h}, 48 \mathrm{~h} \text { and other } \\
\text { concentrations) }\end{array}$ & [58] \\
\hline $\begin{array}{l}\alpha \text {-tomatine and } \\
\text { hydrolysis }\end{array}$ & $\mathrm{PC} 3$ prostate cancer & $1,10,50,100$ & $\begin{array}{c}\mathrm{IC}_{50}=3.0 \pm 0.3 \text { for } \alpha \text {-tomatine, } 82.5 \pm 9.6 \text { for } \\
\beta_{1} \text {-tomatine, } 103.2 \pm 16.6 \text { for } \gamma \text {-tomatine, } \\
100.5 \pm 5.0 \text { for } \delta \text {-tomatine, and } 248.9 \pm 11.2 \\
\text { for tomatidine (all in } \mu \mathrm{g} \mathrm{mL}-1, \text { all } 48 \mathrm{~h} \text { ) }\end{array}$ & [54] \\
\hline
\end{tabular}

Even at sub-toxic doses $(<1.5 \mu \mathrm{M}), \alpha$-tomatine was found to suppress the invasion and migration ability of a non-small cell lung cancer line (assessed by the ability of the cells to pass through filters coated with Matrigel) by inactivating the PI3K/Akt signaling pathway [51]. A study of the effect of tomatine ( 6 or $9 \mu \mathrm{M}$ ) on MCF-7 human breast adenocarcinoma cells revealed that $\alpha$-tomatine did not cause apoptosis and that the treated cells died by necrosis due to membrane disruption [57]. The absence of apoptosis was determined by assays for proteins p53, phosphorylated p53, and p21 and no change was seen in the levels of these proteins, additionally no caspase- 8 or caspase- 9 activity was observed. However, loss of adenosine triphosphate (ATP) from treated cells was observed. Microscopy observation over a $72 \mathrm{~h}$ period for cells treated with $9 \mu \mathrm{M} \alpha$-tomatine showed that after $24 \mathrm{~h}$ cell proliferation was greatly reduced with cells breaking away from the substrate and rupturing to release their contents; however, by $72 \mathrm{~h}$ cell proliferation had recovered. The observations showed no evidence for blebbing (bulging and protrusion on the cell membranes) that is commonly seen in apoptosis. TEM observations of treated cells showed evidence for swelling and disintegration of both nuclear and 
plasma membranes, indicating necrosis (see Figure 3). The mechanism of membrane disruption was described as the complex formation of cholesterol with $\alpha$-tomatine followed by lateral aggregation of the complexes driven by carbohydrate-carbohydrate interaction that resulted in the loss of membrane integrity. The decrease over time of $\alpha$-tomatine concentration in the cell medium from $2.49 \mathrm{mM}$ to $0.75 \mathrm{mM}$ after $72 \mathrm{~h}$ was attributed to complexation and precipitation of complexes formed with cholesterol in the medium. The cytotoxic action of $\alpha$-tomatine on PC-3 human prostate adenocarcinoma cells was examined in detail [61]. After $24 \mathrm{~h}, \mathrm{IC}_{50}=1.67 \pm 0.3 \mu \mathrm{M}$ was found for the PC-3 cells by MTT assay versus $3.85 \pm 0.1 \mu \mathrm{M}$ for RWPE-1 normal prostate cells. Evidence for a range of apoptotic mechanisms was found including, an increase in Annexin V positive staining over time, increasing permeability to propidium iodide indicating late-stage apoptosis, activation of caspases-3, -8 , and -9 as early as one hour after treatment, inhibition of TNF- $\alpha$ induced NF- $\kappa B$ translocation, and inhibition of $\mathrm{NF}-\mathrm{kB} / \mathrm{p} 50$ and NF-kB/p65 nuclear translocation.

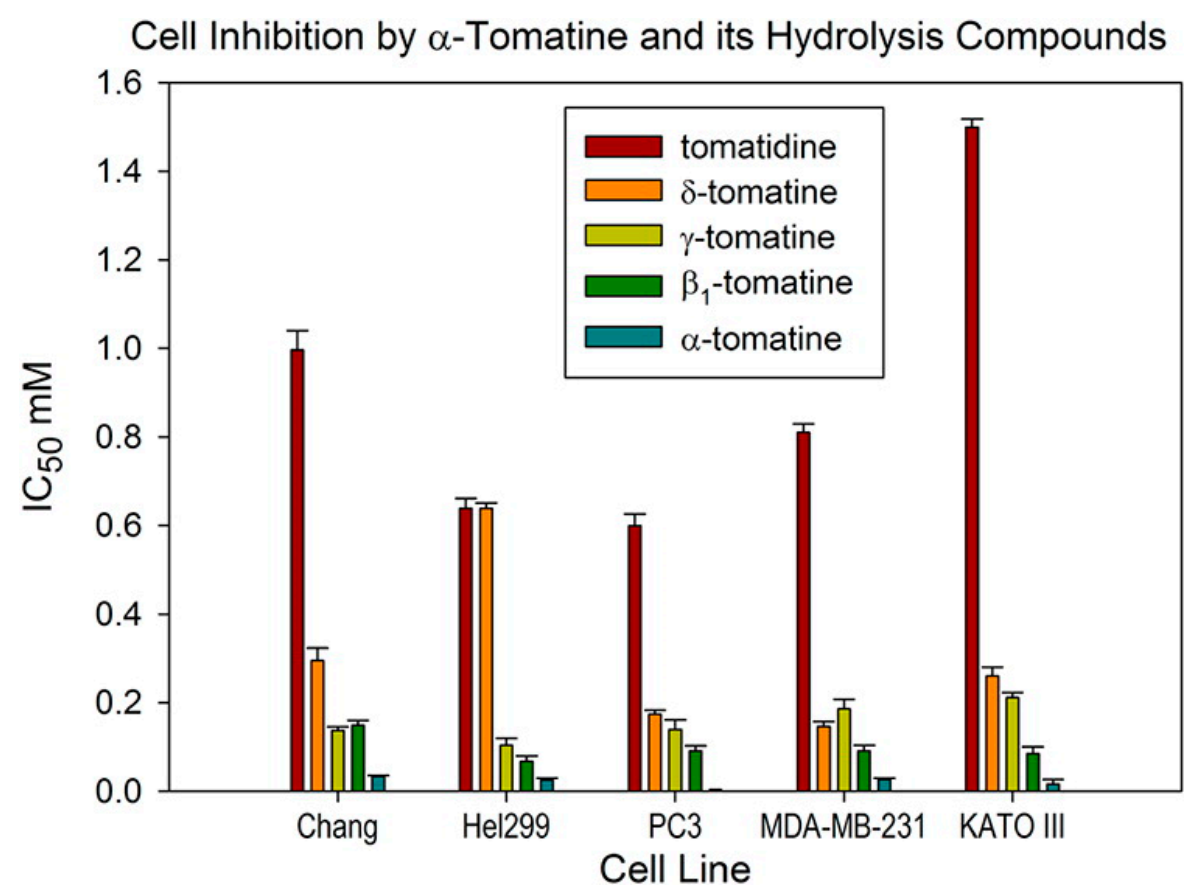

Figure 2. $\mathrm{IC}_{50}$ values determined for $\alpha$-tomatine, $\beta_{1}$-tomatine, $\gamma$-tomatine, $\delta$-tomatine, and the aglycone tomatidine against cancer cells lines PC3 (prostate), MDA-MB-231 (breast), and KATO III (gastric). Chang cell line is normal human liver, and HeI299 is normal human lung cells. The MTT cell viability assay was applied after $48 \mathrm{~h}$. Reproduced from reference [54] with permission, copyright 2012 American Chemical Society.

The activity of $\alpha$-chaconine and $\alpha$-solanine against a number of cancer cell lines have been examined. $\alpha$-Chaconine and $\alpha$-solanine were tested against cervical, liver, lymphoma, and stomach cancer cell lines and also against normal liver cells [55]. Concentration-dependent cytotoxicity was observed over the range $0.1-10 \mu \mathrm{g} \mathrm{mL}^{-1}$. Chaconine was more effective than solanine and some mixtures of the two showed synergistic effects especially against HepG2 liver cancer cells. It is also worth noting that some mixtures of the two showed antagonistic effects. HT-29 human colon cancer cells treated with chaconine were found to show evidence for apoptosis by the enhanced activity of caspase-3 [49]. The mechanism by which $\alpha$-chaconine induces apoptosis in these cells was mediated by ERK1/2 (extracellular signal-related kinase) that is involved in regulating cell survival and cell death. Exposure of cells to $5 \mu \mathrm{g} \mathrm{mL}{ }^{-1} \alpha$-chaconine showed after $24 \mathrm{~h}$ decreased phosphorylation of ERK1/2. Addition of an inhibitor PD98059 of ERK1/2 resulted in an additional increase in caspase-3 activity. HT-29 human colon cancer cells were found to be more susceptible than human prostate cancer cells to 
glycoalkaloid extracts from tubers of Solanum jamesii [62]. It was found that $5 \mu \mathrm{g} \mathrm{mL}{ }^{-1}$ was sufficient to reduce the proliferation of HT-29 cells while $10 \mu \mathrm{g} \mathrm{mL}-1$ was required to reduce the proliferation of human prostate cancer cells. A study of extracts from 13 genetic breeding clones of potato showed that extracts from immature tubers were the most effective against HT-29 cells, and also found an increase in caspase- 3 activity. The cytotoxicity against HT-29 colon cancer cells and HepG2 liver cancer cells was examined for partial hydrolysis products $\beta_{1}$-chaconine, $\beta_{2}$-chaconine, $\gamma$-chaconine, $\beta_{2}$-solanine, and the aglycones [58]. Removal of sugars from $\alpha$-chaconine and $\alpha$-solanine resulted in a decrease in the effectiveness at a given concentration for inhibiting cell growth although inhibition was still observed. At a concentration of $1 \mu \mathrm{g} \mathrm{mL} \mathrm{L}^{-1}$, chaconine (and tomatine) were more effective at inhibiting the growth of HepG2 cancer cells than the DNA intercalating drugs doxorubicin and camptothecin.


Figure 3. Transmission electron micrographs representative of MCF-7 cells. Confluent cells (60-70\%) were treated with $6 \mu \mathrm{M}$ of $\alpha$-tomatine for $4 \mathrm{~h}$. Images of transverse sections of the cells are shown. (A) Control cells, (B) $\alpha$-tomatine-treated cells. The treated cells show the disintegration of both the outer and nuclear membranes, but no typical morphologic signs of apoptosis. Reproduced from reference [57].

The cytotoxic effects of $\alpha$-solamargine and $\alpha$-solasonine from eggplant have also been studied [60]. The cytotoxicity of 20 steroidal glycosides and aglycones against cell lines for lung (PC-6), breast (MCF-7), stomach (NUGC-3), mouse leukemia (P388), and colon (SW620) was evaluated along with cis-platin and 5-fluorouracil (5-FU). The effect on cell growth was measured after $72 \mathrm{~h}$ for 500-5000 cells in well plates. The concentration required to reduce the cell growth rate by $50 \%$ (growth inhibition-50, GI 50 ) after $72 \mathrm{~h}$ was determined and $\alpha$-solamargine was most effective against the P388 cells $\left(\mathrm{GI}_{50}=1.54 \mu \mathrm{g} \mathrm{mL}^{-1}\right)$ and least against prostate cancer cells $\left(\mathrm{GI}_{50}=2.66 \mu \mathrm{g} \mathrm{mL}^{-1}\right)$. In contrast, $\alpha$-solasonine was less effective, being most effective for the SW620 cells $\left(\mathrm{GI}_{50}=6.72 \mu \mathrm{g} \mathrm{mL}^{-1}\right)$ and least effective for the PC-6 cells $\left(\mathrm{GI}_{50}=14.40 \mu \mathrm{g} \mathrm{mL}-1\right)$. In comparison, the cytotoxicity of 5-FU against these cell lines ranged from $\mathrm{GI}_{50}=0.06 \mu \mathrm{g} \mathrm{mL}^{-1}$ for P388 cells to $\mathrm{GI}_{50}=2.21 \mu \mathrm{g} \mathrm{mL}{ }^{-1}$ for NUGC-3 cells and for cis-platin from 
$\mathrm{GI}_{50}=0.01 \mu \mathrm{g} \mathrm{mL}^{-1}$ for P388 cells to $\mathrm{GI}_{50}=2.95 \mu \mathrm{g} \mathrm{mL}{ }^{-1}$ for MCF-7 cells. Against these same cell lines, $\alpha$-solanine was only effective against PC-6 $\left(\mathrm{GI}_{50}=15.70 \mu \mathrm{g} \mathrm{mL}^{-1}\right)$ and P388 cells $\left(\mathrm{GI}_{50}=8.29 \mu \mathrm{g} \mathrm{mL}^{-1}\right)$, while the cytotoxicity of $\alpha$-chaconine ranged from $1.43 \mu \mathrm{g} \mathrm{mL}^{-1}$ for NUGC-3 cells to $1.83 \mu \mathrm{g} \mathrm{mL}^{-1}$ for PC- 6 cells. The total synthesis of $\alpha$-solamargine has been achieved and testing against seven different cancer cell lines [59] and $\mathrm{IC}_{50}$ values were reported for HeLa (cancer), A549 (lung), MCF-7 (breast), K562 (chronic myelogenous leukemia), HCT116 (colon), U87 (glioblastoma), and HepG2 (liver) cancer cells. The $\mathrm{IC}_{50}$ values reported for $\alpha$-solamargine were (in $\left.\mu \mathrm{M}\right): 6,8,2.1,5.2,3.8,3.2$, and 2.5 , respectively. All of these values are lower than those found for cis-platin, which ranged from $17 \mu \mathrm{M}$ to greater than $30 \mu \mathrm{M}$. The cytotoxicity against two normal cell lines (HL7702, liver, and H9C2, myoblast) was greater and found to be $13.5 \mu \mathrm{M}$ and greater than $20 \mu \mathrm{M}$ indicating greater susceptibility of the cancer cell lines. The effect of $\alpha$-solasonine and $\alpha$-solamargine on eight cancer cells lines was compared and the detailed mechanism of cytotoxicity evaluated for one of the cell lines [60]. The cell lines included epidermoid carcinoma (A-431), gastric cancer (BGC-803), hepatocellular carcinoma (SMMC-7721), breast cancer (Bcap-37, T47D, MCF-7, MDA-MB-231, and MDA-MB-453) and also four normal human cells lines (liver L-02, lung epithelial BEAS-2B, kidney proximal tubule HK-2, and breast epithelial cells MCF-10A). Cytotoxicity was determined using the MTT assay after $24 \mathrm{~h}$. The $\mathrm{IC}_{50}$ values determined were all significantly lower for $\alpha$-solamargine than for $\alpha$-solasonine; for example, $\mathrm{IC}_{50}=1.31 \pm 0.34 \mu \mathrm{M}$ for $\alpha$-solamargine for MCF-7 cells while IC $_{50}=13.24 \pm 0.88 \mu \mathrm{M}$ for $\alpha$-solasonine acting against MCF-7 cells. Toxicity was also observed against the four normal cell lines. Detailed cellular studies of the activity against the Bcap-37 cells showed signs of apoptosis including mitochondrial depolarization, cell membrane damage and positive staining by Annexin $V$, the release of cytochrome $c$, upregulation of Bax, and the downregulation of Bcl-2 and Bcl-xL and caspase expression. While the apoptotic effects were similar for $\alpha$-solamargine and $\alpha$-solasonine, their magnitude was greater for $\alpha$-solamargine.

Trastuzumab is a humanized monoclonal antibody that targets the HER2 (human epidermal growth factor) receptor found on breast cancer cells and in many other cancers. Combining $\alpha$-solamargine with Trastuzumab was found to yield a synergistic improvement in the inhibition of cell proliferation [14]. In this study, the inhibition of the growth of $\mathrm{H} 661$ and $\mathrm{H} 69$ lung cancer cell lines by solamargine alone was time-dependent and was at maximum at $18 \mathrm{~h}$, reported as $\mathrm{ED}_{75}=6.83 \mu \mathrm{M}$ for the $\mathrm{H} 661$ cell line and $\mathrm{ED}_{75}=9.34 \mu \mathrm{M}$ for the $\mathrm{H} 69$ cell line $\left(\mathrm{ED}_{75}=\right.$ effective dose for $75 \%$ inhibition). The cell proliferation was determined by measuring incorporation of $\left[{ }^{3} \mathrm{H}\right]$ thymidine into newly synthesized DNA. Exposure of cells to $\alpha$-solamargine was found to increase the expression of HER2. The isobologram method was used to evaluate synergism in the cytotoxicity of the combination of $\alpha$-solamargine at the ED50 concentration and Trastuzumab $\left(50\right.$ or $200 \mu \mathrm{g} \mathrm{mL}^{-1}$ ). The combination index $\mathrm{CI}$ is equal to $\mathrm{D}_{\mathrm{SMX}} / \mathrm{IC} \mathrm{X,SM}$ $+\mathrm{D}_{\text {agent } \mathrm{X}} / \mathrm{IC}_{\mathrm{X} \text {,agent }}$ and is related to synergism for the effect $\mathrm{X}$. In this case, $\mathrm{X}$ is $50 \%$ cell survival $\left(\mathrm{D}_{\mathrm{SMX}}=\right.$ concentration of $\alpha$-solamargine used in combination with $\mathrm{D}_{\text {agentX }}=$ concentration of drug, $\mathrm{IC}_{\mathrm{X}, \mathrm{SM}}=$ concentration of $\alpha$-solamargine alone needed to produce the effect $\mathrm{X}, \mathrm{IC}_{\mathrm{X} \text {,agent }}=$ concentration of drug alone needed to produce the effect $X$ ). A value of $\mathrm{CI}<1.0$ indicates synergism and for the combination of $\alpha$-solamargine and Trastuzumab values of $\mathrm{CI}=0.69 \pm 0.08$ for $\mathrm{H} 661$ and $0.54 \pm 0.03$ for $\mathrm{H} 69$ cells were found. In combination with the DNA binding drug epirubicin, $\alpha$-solamargine showed a very small synergism with $\mathrm{CI}=0.95 \pm 0.01$ for $\mathrm{H} 661$ and $0.92 \pm 0.02$ for $\mathrm{H} 69$ cells.

Synergistic effects against T47D human breast cancer cells were also observed for the combination of $\alpha$-solamargine and doxorubicin [15]. In this study, $\alpha$-solamargine was present as the main component of the extract from Solanum nigrum (leunca) herb. The $\mathrm{IC}_{50}$ for the leunca ethanolic extract was $57 \mu \mathrm{g} \mathrm{mL}$ and that for doxorubicin was $15 \mathrm{nM}$. The inhibition of cell viability was determined for combinations of doxorubicin and leunca extract and the combination index was found to indicate synergism for four specific combinations: $4 \mathrm{nM}$ doxorubicin and either 4,6 , or $18 \mu \mathrm{g} \mathrm{mL} \mathrm{L}^{-1}$ of extract and $1.5 \mathrm{nM}$ doxorubicin with $18 \mu \mathrm{g} \mathrm{mL}^{-1}$ of extract yielding combination indices of $0.59,0.81,0.75$, and 0.79 , respectively. It was also observed that many other combinations of doxorubicin with leunca extract showed antagonism in their effect on cell viability with $C I$ values $>1.0 . \alpha$-solamargine induced apoptosis in three human breast cancer cell lines (HBL-100, SK-BR-3, and 2R-75-1) and showed synergistic effects 
when applied in combination with cisplatin [16]. Application of $\alpha$-solamargine alone was found to be more cytotoxic than a range of common chemotherapy agents including cisplatin, methotrexate, 5 -fluorouracil, epirubicin, and cyclophosphamide. $\alpha$-solamargine was found to upregulate both intrinsic (tumor necrosis factor receptor I (TNFR-I), Fas receptor (Fas), TNFR-I-associated death domain (TRADD), and Fas-associated death domain (FADD)) and extrinsic (upregulation of Bax, downregulation of Bcl-2) apoptosis pathways. The occurrence of apoptosis was confirmed by morphological features including chromatin condensation, shrinkage, and blebbing. The combination of $\alpha$-solamargine and cisplatin $\left(150 \mathrm{mM}\right.$ cisplatin and $\alpha$-solamargine at the $\left.\mathrm{IC}_{25}\right)$ resulted in synergistic effects on reduced cell survival and specifically in the release of cytochrome $c$ from mitochondria and upregulation of pro-apoptotic Bax and downregulation of anti-apoptotic Bcl-2 and Bcl-xL.

A smaller number of studies have focused on the effect of glycoalkaloids on cancer in vivo in animal models [63-65]. The extract of the Brazilian fruit Solanum lycocarpum contains $\alpha$-solamargine and $\alpha$-solasonine and was tested for both anti-carcinogenic and anti-genotoxic effected in rats [63]. Male Wistar rats were injected twice a week with the carcinogen 1,2-dimethylhydrazine at $40 \mathrm{mg}$ per $\mathrm{kg}$ of body weight and after being euthanized after two weeks their colons were excised and evaluated for aberrant crypt foci (ACF), abnormal tube-like cellular formations that are precursors to polyps. Those rats who also received S. Lycocarpum extract at 15,30, or $60 \mathrm{mg}$ per $\mathrm{kg}$ of body weight showed markedly fewer ACF which demonstrated an anti-carcinogenic effect. An anti-genotoxic effect was also observed for rats receiving the extract using the micronucleus and comet assay on bone marrow or liver cells harvested $24 \mathrm{~h}$ after administering methyl methanesulfonate on the 14th day. The extract of Solanum incanum contains $\alpha$-solamargine as its main active ingredient and a 65:35 ratio of $\alpha$-solamargine to $\alpha$-solasonine as determined by reverse-phase HPLC [64]. Hairless female mice were subjected to a protocol of irradiation with UV-B (312 nm) to induce papillomas and microinvasive squamous cell carcinomas (MISCC). Treatment with a formulation of the extract (SR-T100) resolved all papillomas within 11 days and $90 \%$ of MISCC within 10 weeks. Examination of the effect of SR-T100 on human squamous cell carcinoma lines confirmed an apoptotic mechanism. Evaluation of SR-T100 on 13 human volunteers with human actinic keratosis (AK) showed successful resolution of the condition upon daily treatment for 16 weeks. CT-26 mouse colon cancer cells were intra-cutaneously transplanted into the backs of mice $\left(10^{6}\right.$ cells) and the effect of daily administration of $5 \mathrm{mg} \alpha$-tomatine per $\mathrm{kg}$ of body weight was studied [65]. Two weeks of treatment reduced the tumor volume by $38 \%$. Analysis of the $\alpha$-tomatine treated cells in vitro showed signs of late apoptosis and necrosis after $24 \mathrm{~h}$. An $\alpha$-tomatine concentration of $3.5 \mu \mathrm{M}$ was determined as resulting in $50 \%$ cell death after $24 \mathrm{~h}$.

\subsection{Use as a Vaccine Adjuvant}

Tomatine has been found to be effective as an adjuvant. Mice immunized with formulations of ovalbumin and tomatine generated the highest antibody titers of three formulations, the other two being ovalbumin and a glycosylamide lipid or a dendrimer, and also greater than that generated using two standard adjuvants alum and incomplete Freund's adjuvant (IFA) [66]. CD8 ${ }^{+}$cytotoxic T lymphocytes were stimulated in mice immunized against ovalbumin using tomatine as the adjuvant, while no such response was seen using alum or IFA [67]. Mice immunized against malaria using a 9-mer peptide Plasmodium berghei circumsporozoite protein and tomatine as adjuvant displayed a delayed onset to infection [19]. Cytotoxic T lymphocyte response and production of interferon- $\gamma$ were increased by the use of tomatine as an adjuvant in this malaria vaccine formulation. All of the five glycoalkaloids mentioned here were tested for anti-malarial activity and $\alpha$-chaconine was found to be the most effective at suppressing malarial infection with $\mathrm{ED}_{50}$ of $4.9 \mathrm{mg} \mathrm{kg}^{-1}$, a therapeutic index of 9 , and $71.38 \%$ suppression of parasitemia. $\alpha$-Chaconine-6-O-sulfate did not show anti-malarial activity, hence inferring that the 6-OH group of $\alpha$-chaconine is important for antimalarial activity [68]. The microstructures formed by the adjuvant formulations have been proposed as important for their physical interaction with antigen-presenting cells and that this interaction was important for their ability to stimulate an immune response [69]. Transmission electron microscopy revealed that the formulation 
of $\alpha$-tomatine, ovalbumin, n-octyl- $\beta$-D-glucopyranoside (OGP), phosphatidylethanolamine and cholesterol showed a major fraction of needle-shaped aggregates 80-160 nm wide and 2-4 $\mu \mathrm{m}$ in length. Tomatine itself in $0.9 \% \mathrm{NaCl}$ formed novel hollow tubular structures from hundreds of $\mathrm{nm}$ to a few microns in length, and with inner and outer wall diameters of approximately 17 and $27 \mathrm{~nm}$, respectively (see Figure 4).

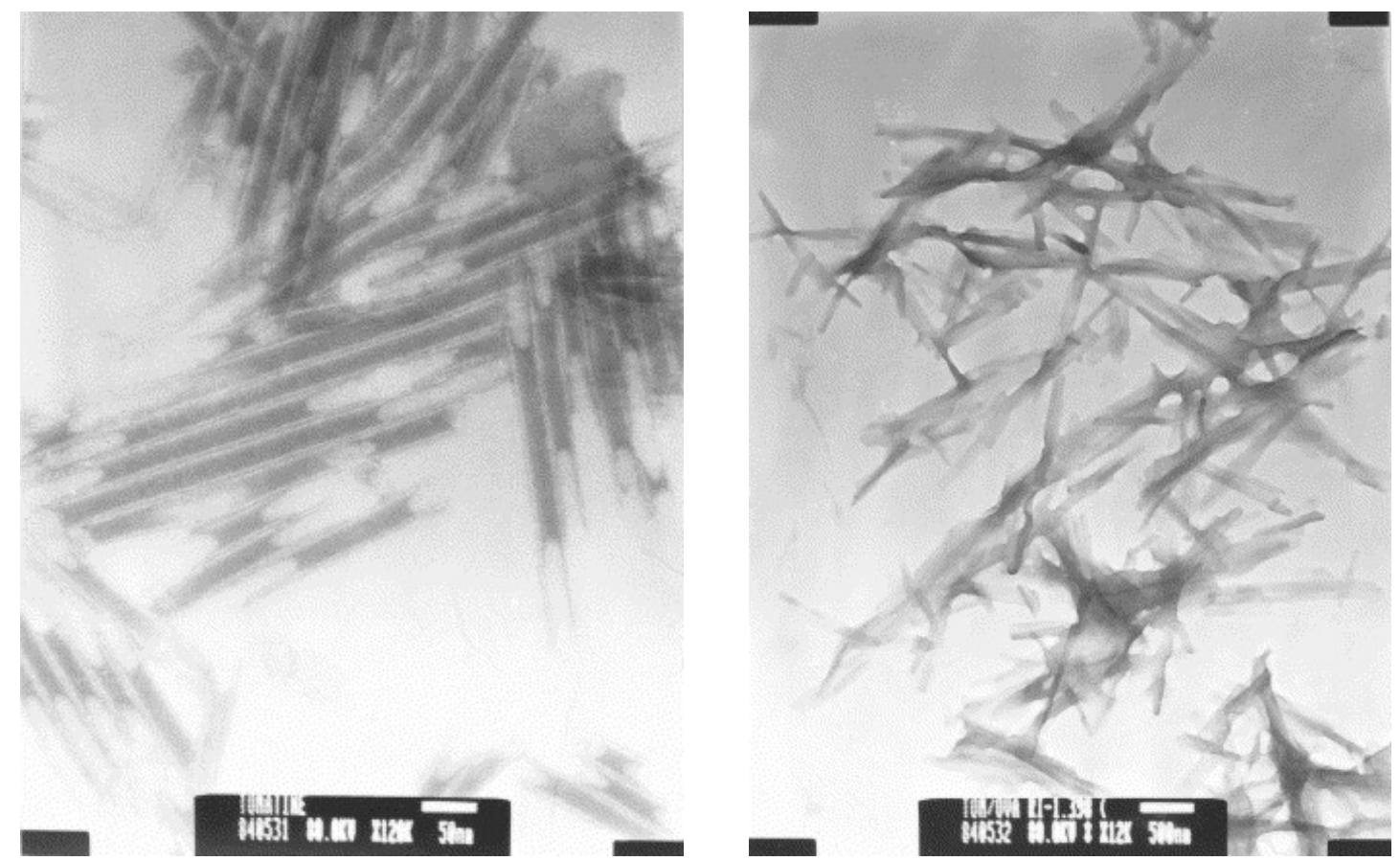

Figure 4. Transmission electron micrograph of tomatine in $0.9 \% \mathrm{NaCl}$, showing its stacking hollow tubular structure (left panel). Transmission electron micrograph of the microstructure of the tomatine adjuvant in the major band after isopycnic ultracentrifugation ( $R I=1.398$ in the sucrose gradient), showing the aggregated gel crystalline microstructure with flaky needle-shaped morphology. Reproduced with permission from reference [69], copyright 2002 (Elsevier).

The adjuvant formulation containing $\alpha$-tomatine and OGP was found to induce both apoptosis and necrosis in EL4 cells (a type of lymphoma cell induced in C57BL mice) and this was proposed to result from membrane disruption and also proposed to promote cross-presentation of antigens to CD8 ${ }^{+}$ $\mathrm{T}$ cells [70]. At lower concentrations of tomatine adjuvant of $5 \mu \mathrm{L} \mathrm{mL}{ }^{-1}$, EL4 cells displayed apoptosis while at higher concentrations both apoptosis and necrosis were observed with $40 \%$ of cells killed by apoptosis and slightly above $40 \%$ by necrosis at $15 \mu \mathrm{L} \mathrm{mL}^{-1}$ of tomatine adjuvant. Treatment of the EL4 cells with $\alpha$-tomatine alone showed apoptosis only for concentrations below $1.0 \mu \mathrm{M}$ at which about $10 \%$ of the cells were dead, and at higher concentration some necrosis with about $10 \%$ of necrotic cells and $60 \%$ apoptotic cells at $10 \mu \mathrm{M} \alpha$-tomatine. Cells treated with OGP showed a higher percentage of late apoptotic/necrotic cells than early apoptotic cells and cells treated with $\alpha$-tomatine alone had a greater percentage of early apoptotic cells than necrotic cells. The percentages of apoptotic and necrotic cells were determined using two-color flow cytometry and staining with FITC conjugated Annexin V, which binds to phosphatidylserines exposed on the cell surface upon apoptosis, and with propidium iodide, which binds to DNA but does not enter viable cells. Apoptotic cell death was observed by confocal fluorescence microscopy, staining the cells with Hoechst 3342, after treating the EL4 cells with $10 \mu \mathrm{M} \alpha$-tomatine for $24 \mathrm{~h}$. The treated EL4 cells showed the features of apoptosis, including DNA cleavage, fragmentation, and chromatin condensation and membrane blebbing. Pretreatment of the cells with caspase inhibitor, zVAD-fmk, did not block cell death indicating caspase-independent apoptosis. 


\section{Interaction of Glycoalkaloids with Liposomes}

The interaction of glycoalkaloids with liposomes of variable compositions has been evaluated. If a $3 \beta$-hydroxysterol is included in the liposome formulation, the glycoalkaloid will generally be observed to promote the leakage of encapsulated components such as dyes or enzymes. Roddick studied the release of peroxidase from liposomes induced by exposure to $\alpha$-tomatine [71]. The activity of $\alpha$-tomatine to cause the release of peroxidase of liposomes composed of egg yolk phosphatidylcholine and cholesterol was maximal at $\mathrm{pH} 7.2$ and decreased as the $\mathrm{pH}$ was decreased towards $\mathrm{pH} 5$. The peroxidase release became significant near $10 \mu \mathrm{M} \alpha$-tomatine and increased up to a concentration near $100 \mu \mathrm{M}$. Achieving a similar release of peroxidase at $\mathrm{pH} 5$ required higher concentrations of $\alpha$-tomatine of $500-1000 \mu \mathrm{M}$. Cholesterol release was more efficient at a given concentration of $\alpha$-tomatine for liposomes containing egg yolk phosphatidylcholine than bovine brain sphingomyelin. The release was monitored by assessing the activity of peroxidase in the supernatant after centrifugation to remove the liposomes into a pellet by monitoring the oxidation of pyrogallol substrate by peroxidase in the presence of $\mathrm{H}_{2} \mathrm{O}_{2}$ to purpurgallin product by an increase in absorbance at $420 \mathrm{~nm}$. The release of peroxidase from multilamellar liposomes composed of egg yolk phosphatidylcholine and cholesterol, stigmasterol or ergosterol with an additional minor component of stearylamine and encapsulating peroxidase induced by solamargine and solasonine was evaluated [72]. $\alpha$-solamargine was found to have significantly more activity for promoting peroxidase release than $\alpha$-solasonine. The combination of $\alpha$-solamargine and $\alpha$-solasonine in 1:1 ratio was found to exhibit significant synergistic effects for promoting lysis of bovine erythrocytes, as measured by hemoglobin release, and of Penicillium notatum protoplasts. Strong synergism was also observed for the release of peroxidase from liposomes of egg yolk phosphatidylcholine and cholesterol. Neither $\alpha$-solamargine nor $\alpha$-solasonine was effective at below neutral $\mathrm{pH}$ [42]. It was found that $\alpha$-chaconine was effective at promoting the release of peroxidase from these liposomes at $100 \mu \mathrm{M}$ and $\mathrm{pH} 7.2$ while solanine was not [73]. The activity of $\alpha$-chaconine was maximal at $\mathrm{pH} 8$, and that of $\alpha$-solanine was almost as great as that of $\alpha$-chaconine at $\mathrm{pH}=9$. Strong synergism for the release of peroxidase from these liposomes was also observed at $\mathrm{pH} 7.2$ for an equimolar solution of $75 \mathrm{mM} \alpha$-chaconine $+75 \mathrm{mM} \alpha$-solanine. The observation of a strong synergistic effect suggests the formation of some sort of ternary complex of both glycoalkaloids with cholesterol. Synthetic modification of solamargine, such as the opening of one of the rings or introduction of nitroso groups produced derivatives that were not effective at disrupting membranes [74].

Keukens et al. conducted a series of studies of glycoalkaloid interactions with liposomes [75]. The action of $\alpha$-tomatine, $\alpha$-chaconine, $\alpha$-solanine, and $\alpha$-solanidine (aglycone of $\alpha$-solanine) against large unilamellar liposomes prepared by extrusion of egg yolk phosphatidylcholines with or without cholesterol through polycarbonate filters with $0.4 \mathrm{~mm}$ diameter pores. Liposomes were prepared with either none or $50 \mathrm{~mol} \%$ cholesterol. The liposomes were loaded with the dye 6-carboxyfluorescein. Sterols including cholesterol, the fungal sterol ergosterol, the plant sterol $\beta$-sitosterol, and fucosterol (found in algae) were included in liposome formulations. The dye release was monitored by an increase in fluorescence (excitation wavelength $=430 \mathrm{~nm}$, emission wavelength $=513 \mathrm{~nm}$ ) due to the de-quenching that occurs when the dye was released from inside the liposomes. Liposomes without cholesterol showed no leakage of dye when exposed to up to $200 \mu \mathrm{M} \alpha$-solanine or $\alpha$-chaconine or very minor with $\alpha$-tomatine up to $200 \mu \mathrm{M}$ while solanidine caused about $20 \%$ leakage. For liposomes with $50 \mathrm{~mol} \%$ cholesterol, $\alpha$-tomatine at $50 \mathrm{mM}$ and $\alpha$-chaconine at $100 \mathrm{mM}$ caused a complete release of dye within five minutes. In contrast, $\alpha$-solanine caused a minor release of dye. The effectiveness in causing dye release was in the order $\alpha$-tomatine $>\alpha$-chaconine $>\alpha$-solanidine $>\alpha$-solanine. The percentage of glycoalkaloid bound to cholesterol-containing liposomes was found to be $75 \pm 2 \%$ at $100 \mu \mathrm{M}$ for $\alpha$-chaconine versus $14 \pm 2 \%$ for $\alpha$-solanine. Variation of cholesterol fraction in the liposomes revealed that $10 \mathrm{~mol} \%$ cholesterol or greater was needed to observe dye release induced by $\alpha$-chaconine. The sterol identity was also found to influence the extent of release, and with $\alpha$-solanine extensive release of dye was seen for liposomes containing $\beta$-sitosterol or fucosterol. These results indicate that the extent of release of dye from the liposome interiors depends on both the sterol structure 
and that of the oligosaccharide on the aglycone in ways that have not yet been physically elucidated. The authors proposed that the size and nature of the oligosaccharide on the glycoalkaloid which determines carbohydrate-carbohydrate interactions between complexes and the nature of the alkyl group at C-24 of the sterol affecting sterol ring system-aglycone steric interactions were both important determinants of the strength of the interaction between glycoalkaloid and sterol. Freeze-fracture SEM of cholesterol-containing liposomes exposed to $\alpha$-chaconine showed the presence of hemi-tubular structures indicating serious perturbation of the membrane structure. It was proposed that the hemi-tubular structures contained $\alpha$-chaconine+cholesterol complexes. The model proposed for the action of glycoalkaloids on lipid bilayers containing cholesterol involves the first insertion of glycoalkaloid into the bilayer between the acyl chains of lipids. When the cholesterol composition is above a critical value proposed as $10 \mathrm{~mol} \%$, stable glycoalkaloid-cholesterol complexes form due to the interaction between the cholesterol ring system and the aglycone part of the glycoalkaloid structure. The complexes then segregate laterally due to carbohydrate-carbohydrate interactions and result in regions that begin to develop high outward curvature driven by the steric demands of the glycoalkaloids that result in budding of tubular structures from the membrane. Molecular mechanics energy minimization suggested that the glycoalkaloid and sterol align parallel to each other.

In a follow-up study [76], the effect on dye release of additional molecular features of both the sterol and the glycoalkaloid were examined. The hydrolysis products of $\alpha$-tomatine were prepared by hydrolysis and separated by HPLC including $\beta_{1}$-tomatine (w/o xylose), $\beta_{2}$-tomatine (w/o glucose), $\gamma$-tomatine (w/o xylose and glucose), and $\delta$-tomatine (w/o xylose and both glucose units). Removal of just one sugar from $\alpha$-tomatine was found to result in the loss of almost all of the activity for dye release from liposomes of egg yolk phosphatidylcholine that were $50 \mathrm{~mol} \%$ in cholesterol. Dye leakage due to $\alpha$-chaconine was most efficient for liposomes containing cholesterol versus other sterols such as coprostanol, which has a non-planar ring system, or epicholesterol where the hydroxyl group stereochemistry is inverted to be $3 \alpha$. There was little change in dye release for liposomes containing cholestenol in which the double bond of cholesterol is saturated. Strong synergism was observed for dye release upon application of mixtures of $\alpha$-chaconine and $\alpha$-solanine; for a mixture of $20 \mu \mathrm{M}$ $\alpha$-chaconine and $120 \mu \mathrm{M} \alpha$-solanine, the release of dye was enhanced 10-fold over that achieved by $\alpha$-solanine alone as can be seen in Figure 5. $\alpha$-Solanine was not found to form stable complexes with cholesterol. Complexes of cholesterol with $\alpha$-chaconine and those with $\alpha$-solanine were proposed to be held together by especially effective interactions between the sugars of the $\alpha$-chaconine oligosaccharide with the sugars of the $\alpha$-solanine oligosaccharide and the synergistic effects were attributed to this interaction. Molecular modeling gave the lowest energy structure of $\alpha$-solanidine and cholesterol with the methyl groups on the ring structures pointing away from each other such that neighboring complexes could associate in a matrix made favorable as the second-lowest energy structure had the methyl groups pointing towards each other. The formation of the irreversible glycoalkaloid-sterol matrix causes sterols from the inner leaflet to flip to replace them. Budding from the membrane and separation occurs with the structure having an inner lining of phospholipid from the inner leaflet of the bilayer. Freeze fracture SEM of liposomes exposed to the glycoalkaloids showed tubular and spherical structures for $\alpha$-tomatine and tubular structures for $\alpha$-chaconine.

The effects of $\alpha$-tomatine, $\alpha$-chaconine, and $\alpha$-solanine on the membrane integrity for human erythrocytes, human colorectal carcinoma cells (Caco-2 cells), and mitochondria were also examined [77]. The glycoalkaloids caused a release of hemoglobin from human erythrocytes with the order of effectiveness being $\alpha$-tomatine $>\alpha$-chaconine $>\alpha$-solanine with large differences such that release of $50 \%$ of the hemoglobin required about $3 \mu \mathrm{M} \alpha$-tomatine, $20 \mu \mathrm{M} \alpha$-chaconine, and $100 \mu \mathrm{M} \alpha$-solanine. The glycoalkaloids had the same order of effectiveness for promoting the release of lactate dehydrogenase or $\mathrm{Ca}^{2+}$ from Caco-2 cells. The order of effectiveness is determined by the strength of interaction of the glycoalkaloid with cholesterol to form complexes and this order of effectiveness is the same as that seen for the model membrane systems. Membrane disruption by glycoalkaloids requires significant cholesterol content in the membrane, and human erythrocytes contain about $50 \%$ cholesterol. 
The disruption of mitochondrial membranes was measured by following the release of the enzyme adenylate kinase. It has also been reported that 1:1 mixtures of $\alpha$-chaconine and $\alpha$-solanine exhibited a synergistic effect in the disruption rabbit erythrocytes, red beet cells and Penicillium notatum protoplasts but when used alone $\alpha$-chaconine showed greater activity.



Figure 5. Glycoalkaloid induced leakage of the dye carboxyfluorescein from liposomes of egg yolk phosphatidylcholine containing (A) cholesterol or (B) fucosterol. The leakage was measured $5 \mathrm{~min}$ after addition of the indicated amounts of $\alpha$-chaconine (open circles), $\alpha$-solanine (solid circles), or an equimolar mixture of the two. Synergistic effects are clearly seen. Reproduced with permission from reference [76], copyright 1995 (Elsevier).

\section{Interaction of Glycoalkaloids with Monolayers at the Air-Water Interface}

Study of the interactions of $\alpha$-tomatine with phospholipid + sterol monolayers has been of interest as a step toward the further physical characterization of the interaction of these compounds with model membrane systems. Monolayers of lipids and sterols spread at the water surface can be subject to a range of physical measurements including surface pressure measurements, microscopy observations, and spectroscopic interrogation by methods such as reflectance infrared spectroscopy [78]. The activity of $\alpha$-tomatine and some saponins as adjuvants may be related to their ability to permeabilize antigen-presenting cells [70] and their membrane disrupting activity could be a main feature of their ability to inhibit the growth of cancer cells [11,12].

The interaction of $\alpha$-tomatine with monolayers spread at the air-water interface was studied in experiments in which the monolayer was first compressed to fixed surface pressure and then a portion of the water surface captured by closing a small canal between the larger Langmuir trough and a smaller inserted Teflon trough [79]. The increase in surface pressure over time was followed after injection of a specified concentration of glycoalkaloid with very gentle stirring. Monolayers of pure sterols chosen for their systematic structural variation included cholesterol, cholestanol (saturation of double bond), cholestenone (hydroxyl group replaced by ketone), coprostanol (non-planar ring system), epicholesterol (inversion of stereochemistry from $3 \beta-\mathrm{OH}$ to $3 \alpha-\mathrm{OH}$ ), and epicoprostanol (non-planar ring system and inversion of stereochemistry from $3 \beta-\mathrm{OH}$ to $3 \alpha-\mathrm{OH}$ ). After compressing a sterol monolayer to $10 \mathrm{mN} \mathrm{m}^{-1}$ on a subphase of $\mathrm{pH} 70.05 \mathrm{M}$ phosphate buffer in $0.10 \mathrm{M} \mathrm{NaCl}, \alpha$-tomatine was injected so that the concentration in the subphase was $1.3 \mu \mathrm{M}$. Over a period of about one hour, very large increases in surface pressure of about $40 \mathrm{mM} \mathrm{m}^{-1}$ were observed for both cholesterol and cholestanol. Approximately half as much of a surface pressure increase was observed for cholestenone, epicholesterol, and coprostanol, while for epicoprostanol and small surface pressure increase of near $5 \mathrm{mN} \mathrm{m}^{-1}$ was observed. These results demonstrated that perturbing the structure of the sterol away from that of cholesterol in significant ways reduced the strength of the interaction of $\alpha$-tomatine at the 
interface. It should be emphasized that $\alpha$-tomatine alone does not form a stable monolayer and when spread at the water surface and compressed will not register a surface pressure. Injection of $\alpha$-tomatine beneath a monolayer of the phospholipid dimyristoylphosphatidylcholine (DMPC) alone did not result in an increase in surface pressure. Interaction of $\alpha$-tomatine with spread monolayers of 7:3 mole ratio DMPC and sterol were evaluated. During the interaction, the morphology of the monolayers was observed using Brewster angle microscopy (BAM). BAM involves imaging the monolayer reflectivity at an angle. In earlier model BAMs the focus was not consistent across an entire image [80]. The choice of DMPC and the ratio of 7:3 mole ratio was made so that the initial morphology of the monolayer would be featureless and representative of a uniform one phase region. Surface pressure increases in the range of $25 \mathrm{mN} \mathrm{m}^{-1}$ were observed for the mixed monolayers of DMPC and cholesterol, cholestanol, or coprostanol while much smaller increases were seen for the other sterols all below $5 \mathrm{mN} \mathrm{m}^{-1}$ over $5000 \mathrm{~s}$ with the smallest change seen when epicholesterol was used. The smaller surface pressure increases are seen for monolayers containing sterols that complex less effectively with $\alpha$-tomatine, showing that with less effective complex formation, further insertion of $\alpha$-tomatine into the monolayer becomes less favorable since it is not be segregated into complexes. Most significantly, BAM observation during the time period after injection showed the emergence of island like aggregates in the monolayer for the mixed monolayers of DMPC and sterols other than epicholesterol. For DMPC and cholesterol or with DMPC and cholestanol, the appearance of a woven texture indicated that these domains were very small in size and near the resolution limit of the BAM used of $\sim 4 \mu \mathrm{m}$. For the mixed monolayers of DMPC and epicholesterol, no formation of domains/aggregates was seen upon injection of $\alpha$-tomatine beneath the monolayers. This result is consistent with the results on liposomes containing epicholesterol against which glycoalkaloids were ineffective at promoting dye release [76]. The observation of a surface pressure increase but no domain formation suggests insertion into the monolayer but lack of effective complex formation. Keukens et al. proposed that epicholesterol had a different orientation at the interface that prohibited effective complex formation. For the case of mixed monolayers of DMPC and cholestenone, injection of $\alpha$-tomatine resulted in the formation of only a very small number of indistinct and small domains. An unusual result was obtained for injection of $\alpha$-tomatine beneath monolayers of DMPC and coprostanol with the formation of starfish-shaped domains with the arms all curving counter-clockwise. Such curved and chiral domains have been reported for monolayers of chiral amphiphiles [81]. The result suggests that somehow these complexes are arranging in a chiral packing. However, monolayers of DMPC and epicoprostanol did not show chiral domains and instead showed domains resembling indistinct spots. It was proposed that the $\alpha$-tomatine would insert into the monolayer and complex with sterol and then these complexes would aggregate into islands visible under BAM. The formation of aggregates was seen for a monolayer of DMPC + cholesterol of 9:1 molar ratio (see Figure 6A,B) after injection of $\alpha$-tomatine to give a subphase concentration of $1.0 \mu \mathrm{M}$, and BAM images showing the emergence of bright clusters on the water surface which according to the principle of BAM imaging represent regions of greater thickness or density. In Figure 6C, the effect of $1.0 \mu \mathrm{M}$ tomatine on DMPC + cholesterol monolayers of molar ratio 8:2 show an increased density of aggregates and when the molar ratio is increased to 5:5, the pattern that emerges is of a rippled or wavy texture (Figure 6D).

In a subsequent study [82], the dependence of the surface pressure response of spread monolayers of either 7:3 DMPC and cholesterol or monolayers of egg sphingomyelin and cholesterol was studied as a function of tomatine concentration in the subphase. The surface pressure response was found to vary in a manner that saturated near $2 \mu \mathrm{M}$ for the DMPC and cholesterol mixed monolayers and near $15 \mu \mathrm{M}$ for the sphingomyelin and cholesterol mixed monolayers. These data were fit to a binding isotherm to determine an association constant for insertion of $\alpha$-tomatine into the monolayer for assumed complexation with cholesterol that would lead to the increase of surface pressure. BAM observation showed the emergence and growth of irregular island-like aggregates or a mottled texture as time progressed in the interaction with $\alpha$-tomatine. Association constants, as defined by the model were found to be $12 \times 10^{6} \mathrm{M}^{-1}$ for the 7:3 molar ratio DMPC + cholesterol monolayers and 
$0.48 \times 10^{6} \mathrm{M}^{-1}$ for the 7:3 egg sphingomyelin + cholesterol monolayers. The lower affinity of tomatine for the egg sphingomyelin + cholesterol system does not mean a change in affinity for the cholesterol itself. The difference was attributed to a competitive equilibrium in which the interaction between sphingomyelin and cholesterol is stronger than the interaction between DMPC and cholesterol since sphingomyelin can form a hydrogen bond to cholesterol whereas DMPC cannot. It was also found in this study that spreading 1:1 molar ratio compositions of $\alpha$-tomatine and cholesterol resulted in stable and compressible monolayers while $\alpha$-tomatine itself showed no ability to form a monolayer that registered any surface pressure on compression. The variation of surface pressure with time after injection of tomatine underneath the 7:3 molar ratio DMPC + cholesterol monolayers is shown in Figure 7A and the variation of the maximum longer time surface pressure increases versus $\alpha$-tomatine concentration is shown in Figure 7B. The $\mathrm{pH}$ dependence of $\alpha$-tomatine interaction with DMPC + cholesterol monolayers was also studied for monolayers spread on buffers at $\mathrm{pH}$ values of 5.0, 7.0, and 9.0. It was observed that surface pressure response was drastically lower at $\mathrm{pH} 5.0$ while the changes in surface pressure were comparable for $\mathrm{pH} 7.0$ and 9.0 with a slightly higher response at $\mathrm{pH}$ 7.0 as shown in Figure 8. The reduced response at $\mathrm{pH} 5.0$ was attributed to protonation of the nitrogen on the aglycone of $\alpha$-tomatine. In the case of $\alpha$-tomatine interacting with mixed monolayers of egg sphingomyelin and cholesterol, instability was observed as the surface pressure would rise and then tend to slowly decrease possibly due to some sort of formation of three-dimensional structures which however were not evident under BAM. The estimation of a binding constant for the interaction of $\alpha$-tomatine with these monolayers was conducted using the maximal surface pressure values observed in time plots of surface pressure at the individual $\alpha$-tomatine concentrations.
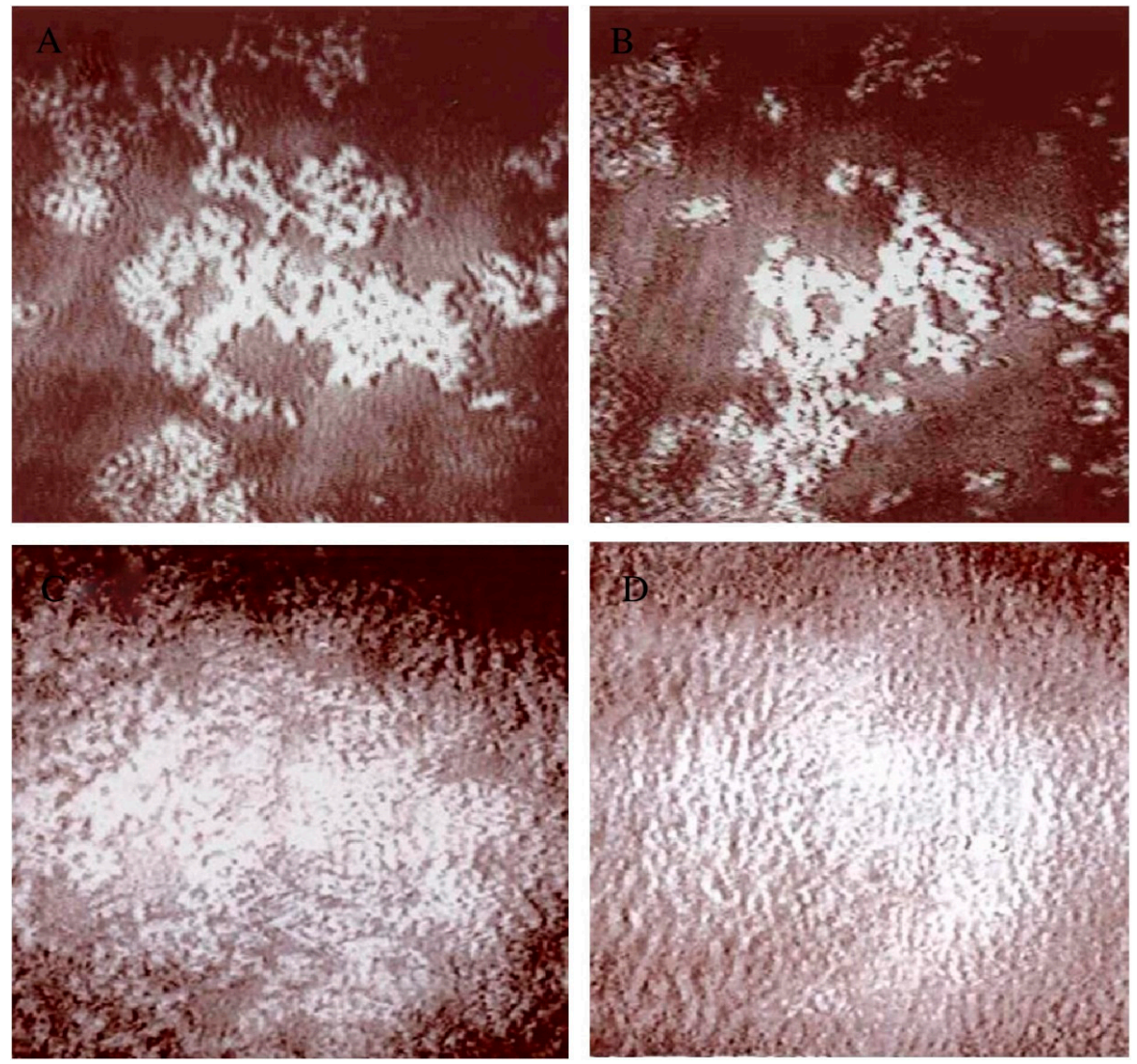

Figure 6. BAM images of DMPC and cholesterol mixed monolayers interacting with 1.0 $\mu$ M tomatine. (A) 9:1 mole ratio at $15 \mathrm{~min}$ after injection, (B) 9:1 mole ratio at $50 \mathrm{~min}$ after injection, (C) 8:2 mole ratio at $120 \mathrm{~min}$ after injection, (D) 5:5 mole ratio at $120 \mathrm{~min}$ after injection. The monolayers were compressed to $10 \mathrm{mN} \mathrm{m}^{-1}$ prior to injection. The images are $700 \mu \mathrm{m} \times 700 \mu \mathrm{m}$. Reproduced with permission from reference [82]. 
Monolayer studies have also been reported for some other saponins. The interaction of digitonin, a cardiac glycoside from the plant Digitalis purpurea, with monolayers of dipalmitoylphosphatidylcholine (DPPC) and cholesterol was examined using surface pressure measurements, surface rheology, fluorescence microscopy, neutron reflectivity, grazing incidence X-ray diffraction (GIXD), and infrared reflection absorption spectroscopy (IRRAS) [83]. Monolayers of DPPC and cholesterol of 10:9 molar ratio were compressed to a pressure of $32.5 \mathrm{mN} \mathrm{m}^{-1}$, theoretically expected to resemble the packing state of natural membranes of erythrocytes. Introduction of $100 \mu \mathrm{M}$ digitonin beneath the monolayer by subphase replacement resulted in an increase in surface pressure to about $55 \mathrm{mN} \mathrm{m}^{-1}$ over a period of $1 \mathrm{~h}$. This surface pressure was higher than the collapse pressure of the mixed monolayer indicating strong interaction of digitonin with the monolayer. A smaller increase to a surface pressure near 40 $\mathrm{mN} \mathrm{m}^{-1}$ was observed for monolayers of DPPC alone. Digitonin dissolved in water was found to be surface-active and to build up a surface pressure from a $100 \mu \mathrm{M}$ solution of $\sim 25 \mathrm{mN} \mathrm{m}^{-1}$. The surface dilational viscoelasticity modulus $|\mathrm{E}|$ which is composed of real part $\mathrm{E}^{\prime}(\mathrm{w})$ and imaginary part $\mathrm{E}^{\prime \prime}(\mathrm{w})$ was found to decrease during the interaction with digitonin from a value of $|E|=205.4 \mathrm{mN} \mathrm{m}^{-1}$ for the DPPC monolayer to $58.5 \mathrm{mN} \mathrm{m}^{-1}$, higher than the value of $18.1 \mathrm{mN} \mathrm{m}^{-1}$ for a Gibbs monolayer of digitonin $(\mathrm{w}=0.1 \mathrm{~Hz})$. This observation was consistent with the retention of some fraction of the DPPC within the monolayer and with the insertion of digitonin weakening interactions between DPPC molecules. In contrast, monolayers of 10:9 mole ratio DPPC to cholesterol showed a large increase in $|E|$ upon interaction with digitonin from $\mathrm{E}^{\prime}=176.5 \mathrm{mN} \mathrm{m}^{-1}$ and $\mathrm{E}^{\prime \prime}=105.0 \mathrm{mN} \mathrm{m}^{-1}$ to $|\mathrm{E}|=421.8 \mathrm{mN} \mathrm{m}^{-1}$ $\left(\mathrm{E}^{\prime}=357.3 \mathrm{mN} \mathrm{m}^{-1}, \mathrm{E}^{\prime \prime}=105.0 \mathrm{mN} \mathrm{m}^{-1}\right)$. This increase indicated the formation of dense structures able to store and release energy upon surface dilation and compression. The neutron reflectivity data were consistent with digitonin being squeezed in between DPPC and cholesterol monolayers. The GIXD data for digitonin beneath DPPC and cholesterol monolayers were consistent with the release of DPPC molecules from their complexes with cholesterol to yield a phase-separated monolayer of DPPC and cholesterol+digitonin complexes. The question of the how the interaction of digitonin with phospholipids with different head-groups revealed a stronger affinity for phosphatidylethanolamine and phosphatidylserine head-groups attributed to hydrogen bond formation between the phospholipid head-group and the hydroxyls on the sugars of the glycan of digitonin [84]. IRRAS data showed that the interaction with digitonin increased monolayer disorder and that water molecules hydrating the phospholipid head-groups were replaced by hydrated digitonin molecules. Quillaja bark saponin, useful as a vaccine adjuvant, was studied using subphase replacement beneath DPPC monolayers at $1.0 \mathrm{mM}$ concentration and found to be able to insert into the monolayer and cause significant surface pressure increase but without causing monolayer collapse [85]. Quillaja bark saponin will adsorb strongly from the subphase to the water-air interface forming what is referred to as a Gibbs monolayer and even at a concentration as low as $3.0 \times 10^{-5} \mathrm{M}$, a surface pressure near $17.5 \mathrm{mN} \mathrm{m}^{-1}$ was observed for the adsorbed layer. The interaction of the saponin $\alpha$-hederin with DPPC + cholesterol monolayers demonstrated that this saponin formed layers beneath the monolayer of complexes with DPPC and with cholesterol [86]. Studies of the interaction of digitonin with supported bilayers were carried out using the quartz crystal microbalance with dissipation method (QCM-d) [87]. The phospholipid used was 1-stearoyl-2-oleoyl-sn-glycero-3-phosphocholine (SOPC) and the supported bilayers were formed by adsorption and unraveling of small unilamellar vesicles. QCM-d showed little effect of digitonin onto supported SOPC bilayers but a significant frequency decrease and a large dissipation increase for supported bilayers containing $20 \mathrm{~mol} \%$ cholesterol. Combining these data with $\mathrm{x}$-ray reflectivity data suggested that digitonin penetrates the supported bilayer and removes cholesterol from the membrane core in order to form complexes. Differential scanning calorimetry (DSC) data showed re-emergence of the main chain melting transition for SOPC in vesicles containing cholesterol, also indicating the removal of cholesterol from its complexes with the phospholipid. 

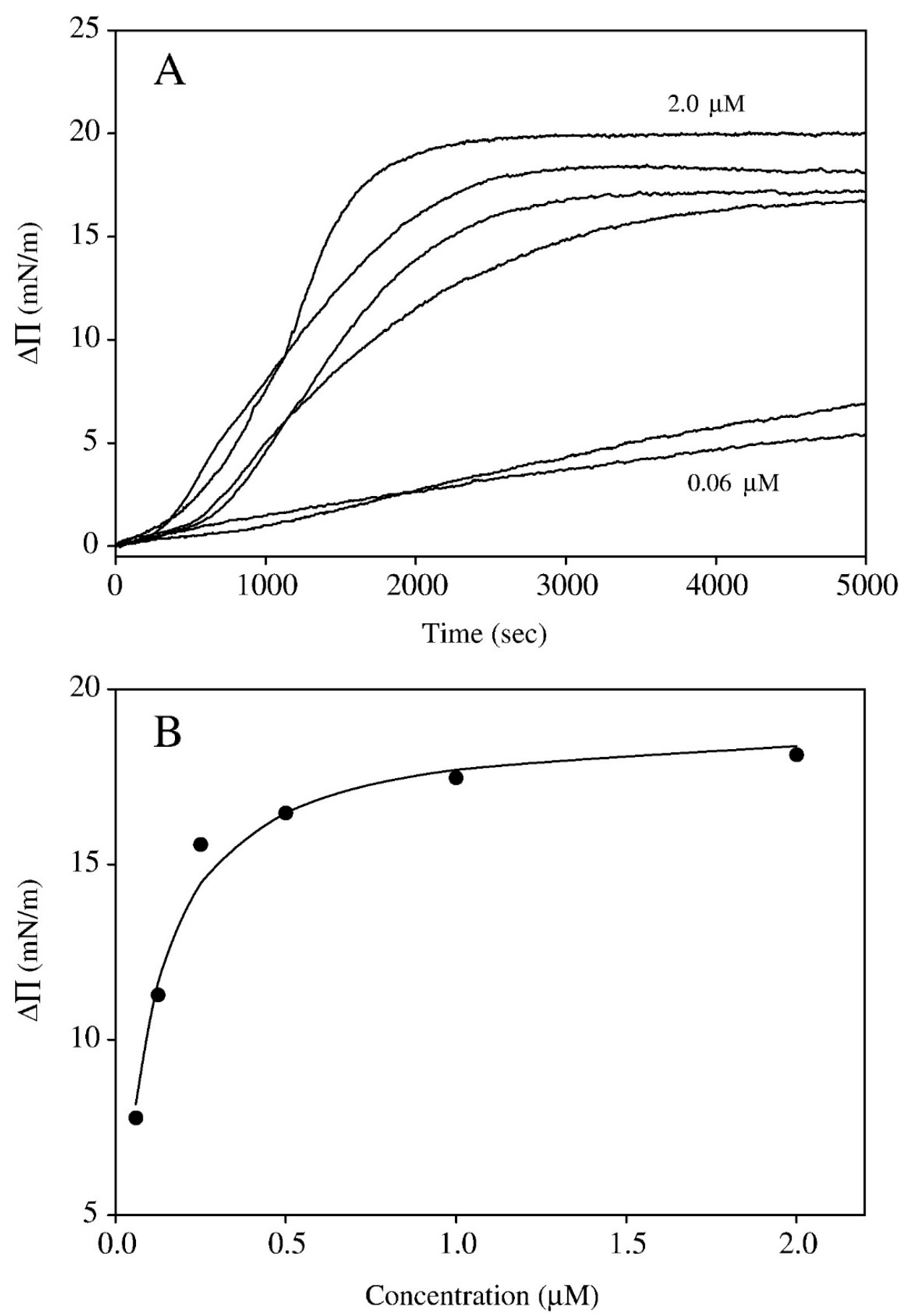

Figure 7. (A) The response of mixed monolayers of 7:3 mole ratio DMPC:cholesterol to injection of varying concentrations of tomatine. The monolayers were compressed to $10 \mathrm{mN} \mathrm{m}^{-1}$ prior to injection. The concentrations studied were $2.0 \mu \mathrm{M}, 1.0 \mu \mathrm{M}, 0.5 \mu \mathrm{M}, 0.25 \mu \mathrm{M}, 0.125 \mu \mathrm{M}$, and $0.06 \mu \mathrm{M}$. At the later times, these curves fall in order of concentration on the graph from lowest to highest. The subphase is $0.05 \mathrm{M} \mathrm{pH} 7.0$ phosphate buffer, $0.10 \mathrm{M} \mathrm{NaCl}$. (B) Binding curve of the measured plateau values of $\Delta \Pi$ at long time plotted versus subphase concentration of tomatine. The $\Delta \Pi$ values for the two lowest tomatine concentrations are determined at much longer times near $12,000-14,000 \mathrm{~s}$. The $\Delta \Pi$ values are an average for two complete data sets. Reproduced with permission from reference [82]. 


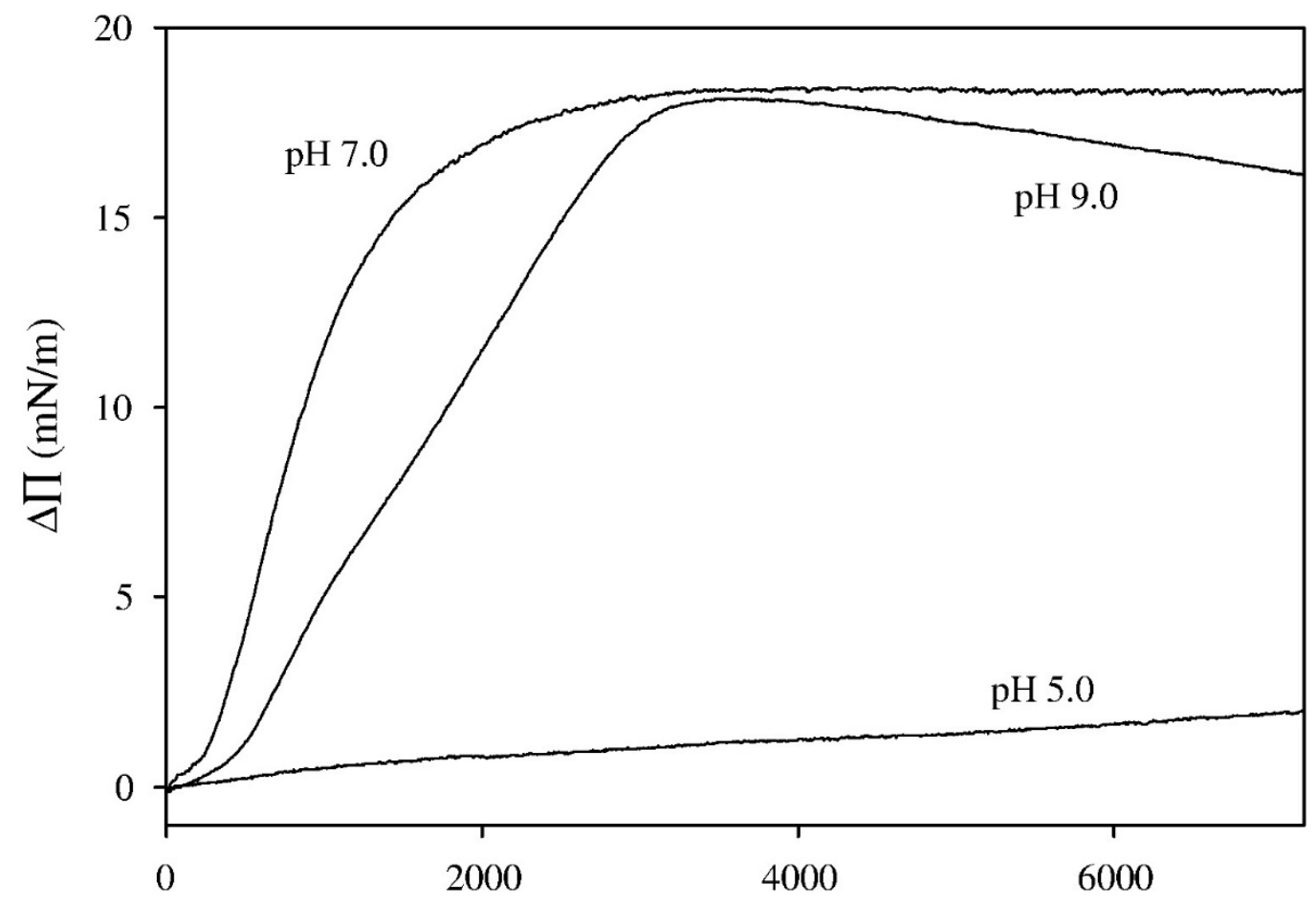

Square Angstroms per Molecule

Figure 8. Surface pressure response $(\Delta \Pi)$ vs. time for mixed monolayers of dimyristoylphosphatidylcholine (DMPC) and cholesterol of 7:3 mole ratio interacting with $1 \mu \mathrm{M}$ tomatine compared on $0.05 \mathrm{M}$ subphases of pH 5.0 (acetate buffer), pH 7.0 (phosphate buffer), and pH 9.0 (borate buffer). The monolayers were compressed to $10 \mathrm{mN} \mathrm{m}^{-1}$ prior to injection. Each subphase contains $0.10 \mathrm{M} \mathrm{NaCl}$. Reproduced with permission from reference [82].

\section{Summary of Key Results}

The glycoalkaloids show clear cytotoxicity at concentrations generally in the low to several micromolar ranges and do not discriminate well between normal and cancerous cells. The preponderance of the detailed cellular studies against various cancer cell lines indicates apoptotic mechanisms, which include morphological effects on membranes. However, some studies point to a necrotic mechanism driven by membrane disruption and some studies show evidence for both apoptotic and necrotic effects. There is much work yet to be done to understand at the molecular level how glycoalkaloids trigger these apoptotic signaling pathways and how these signaling pathways are influenced by changes in membrane structure. The glycoalkaloids can act synergistically with a number of widely used cancer therapeutics but have not yet been commercialized for such formulations. The cytotoxicity is time-dependent and the relative extent of early versus late-stage apoptotic effects can vary with time. The interaction of glycoalkaloids with membranes is driven by their complexation with cholesterol, or other $3 \beta$-hydroxysterols, and is sensitive to stereochemical and steric effects and the extent to which the joining of these complexes into larger structures driven by carbohydrate-carbohydrate interactions and sterol-aglycone packing is favored. Model membrane systems such as liposomes and monolayers, and also potentially supported bilayers although such studies seem mostly lacking, can provide insight into the extent to which selected glycoalkaloids or their mixtures perturb membrane structure. There is clearly room for more extensive molecular modeling studies and for the examination of these complexes and their aggregated structures at the detailed and molecular level. 


\section{Conclusions}

The glycoalkaloids exhibit a number of interesting and potentially useful interactions with cell membranes in their reported roles as anti-cancer agents, anti-fungal agents, and in vaccine adjuvants. While membrane disruption via cholesterol complexation is clearly a main effect, biological data also suggest interference in signaling pathways and interactions with other cell surface receptors. The structural role of the carbohydrate group is crucial and the details of how complexation with sterols depends on subtle features of the molecular structure remains to be elucidated and explained via physical and spectroscopic measurements and molecular modeling calculations. The molecular interactions behind the reported synergistic effects between $3 \beta$-hydroxysterols and pairs of related glycoalkaloids are fascinating and require further study, especially the observation that antagonistic effects may also be seen for certain ratios. It is also not known how glycoalkaloids interact with a fuller variety of lipids with different head-groups such as a broader range of glycolipids. The glycoalkaloids also clearly can promote the formation of highly interesting supramolecular aggregates in the presence of sterols and lipids. As natural products that are readily accessible, their ability to synergistically improve the effectiveness of anti-cancer agents through synergistic effects suggests that their further study and potential therapeutic application is worth pursuing.

Author Contributions: Both authors contributed to the preparation of this review. Each author wrote parts of the manuscript and K.J.S. assembled the final version.

Funding: The authors acknowledge support from the University of Missouri-Saint Louis Office of Research.

Conflicts of Interest: The authors declare no conflict of interest.

\section{References}

1. Mecke, A.; Uppuluri, S.; Sassanella, T.M.; Leeb, D.-K.; Ramamoorthy, A.; Baker, J.A., Jr.; Orra, B.G.; Banaszak Holl, M.M. Direct observation of lipid bilayer disruption by poly(amidoamine) dendrimers. Chem. Phys. Lipids 2004, 132, 3-14. [CrossRef] [PubMed]

2. Xing, K.; Xing, Y.; Liu, Y.; Zhang, Y.; Shen, X.; Li, X.; Miao, X.; Feng, Z.; Peng, X.; Qin, S. Fungicidal effect of chitosan via inducing membrane disturbance against Ceratocystis fimbriata. Carb. Polym. 2018, 192, 95-103. [CrossRef] [PubMed]

3. Papo, N.; Shai, Y. Exploring peptide membrane interaction using surface plasmon resonance: Differentiation between pore formation versus membrane disruption by lytic peptides. Biochemistry 2003, 42, 458-466. [CrossRef] [PubMed]

4. Roddick, J.G. Steroidal glycoalkaloids: Nature and consequences of bioactivity. In Saponins Used in Traditional and Modern Medicine. Advances in Experimental Medicine and Biology; Waller, G.R., Yamasaki, K., Eds.; Springer: Boston, MA, USA, 1996; Volume 404, pp. 277-295.

5. Friedman, M. Tomato glycoalkaloids: role in the plant and in the diet. J. Agric. Food Chem. 2002, 50, 5751-5780. [CrossRef]

6. Ohvo-Rekilä, H.; Ramstedt, B.; Leppimäki, P.; Slotte, J.P. Cholesterol interactions with phospholipids in membranes. Prog. Lipid Res. 2002, 41, 66-97. [CrossRef]

7. Lu, M.-K.; Shih, Y.-W.; Chien, T.-T.C.; Fang, L.-H.; Huang, H.-C.; Chen, P.-S. $\alpha$-Solanine inhibits human melanoma cell migration and invasion by reducing matrix metalloproteinase-2/9 activities. Biol. Pharm. Bull. 2010, 33, 1685-1691. [CrossRef]

8. Shih, Y.-W.; Chen, P.-S.; Wu, C.-H.; Jeng, Y.-F.; Wang, C.-J. $\alpha$-Chaconine-reduced metastasis involves a PI3K/Akt signaling pathway with downregulation of NF-KB in human lung adenocarcinoma A549 cells. J. Agric. Food Chem. 2007, 55, 11035-11043. [CrossRef]

9. Roddick, J.G. The acetylcholinesterase-inhibitory activity of steroidal glycoalkaloids and their aglycones. Phytochemistry 1989, 28, 2631-2634. [CrossRef]

10. Benilova, I.V.; Arkhypova, V.N.; Dzyadevych, S.V.; Jaffrezic-Renault, N.; Martelet, C.; Soldatkin, A.P. Kinetics of human and horse sera cholinesterases inhibition with solanaceous glycoalkaloids: Study by potentiometric biosensor. Pesticide Biochem. Physiol. 2006, 86, 203-210. [CrossRef] 
11. Sucha, L.; Tomsik, P. The steroidal glycoalkaloids from Solanaceae: Toxic effect, antitumour activity and mechanism of action. Planta Med. 2016, 82, 379-387. [CrossRef]

12. Jiang, Q.-W.; Chen, M.-W.; Cheng, K.-J.; Yu, P.-Z.; Wei, X.; Shi, Z. Therapeutic potential of steroidal alkaloids in cancer and other diseases. Med. Res. Rev. 2016, 36, 119-143. [CrossRef]

13. Lee, S.T.; Wong, P.-F.; Hooper, J.D.; Mustafa, M.R. Alpha-tomatine synergises with paclitaxel to enhance apoptosis of androgen-independent human prostate cancer PC-3 cells in vitro and in vivo. Phytomedicine 2013, 20, 1297-1305. [CrossRef]

14. Liang, C.-H.; Shiu, L.-Y.; Chang, L.-C.; Sheu, H.-M.; Tsai, E.-M.; Kuo, K.-W. Solamargine enhances HER2 expression and increases the susceptibility of human lung cancer H661 and H69 cells to Trastuzumab and Epirubicin. Chem. Res. Toxicol. 2008, 21, 393-399. [CrossRef]

15. Sarmoko, A.; Putri, D.D.P.; Hermawan, A.; Meiyanto, E. Combination of Solanum nigrum L. herb ethanolic extract and Doxorubicin performs synergism on T47D breast cancer cells. Indones. J. Cancer Chemoprevent. 2010, 1, 78-84.

16. Shiu, L.Y.; Chang, L.C.; Liang, C.H.; Huang, Y.S.; Sheu, H.M.; Kuo, K.W. Solamargine induces apoptosis and sensitizes breast cancer cells to cisplatin. Food Chem. Toxicol. 2007, 45, 2155-2164. [CrossRef]

17. Morrow, W.J.W.; Yang, Y.-W.; Sheikh, N.A. Immunobiology of the tomatine adjuvant. Vaccine 2004, 22, $2380-2384$. [CrossRef]

18. Heal, K.G.; Sheikh, N.A.; Hollingdale, M.R.; Morrow, W.J.W.; Taylor-Robinson, A.W. Potentiation by a novel alkaloid glycoside adjuvant of a protective cytotoxic $\mathrm{T}$ cell immune response specific for a preerythrocytic malaria vaccine candidate antigen. Vaccine 2001, 19, 4153-4161. [CrossRef]

19. Heal, K.G.; Taylor-Robinson, A.W. Tomatine Adjuvantation of protective immunity to a major pre-erythrocytic vaccine candidate of malaria is mediated via CD8+ T cell release of IFN- $\gamma$. J. Biomed. Biotech. 2010, 834326.

20. Milner, S.E.; Brunton, N.P.; Jones, P.W.; O' Brien, N.M.; Collins, S.G.; Maguire, A.R. Bioactivities of glycoalkaloids and their aglycones from Solanum species. J. Agric. Food Chem. 2011, 59, 3454-3484. [CrossRef]

21. Percival, G.C.; Dixon, G.R. Glycoalkaloids. In Handbook of Plant and Fungal Toxins; Felix D'Mello, J.P., Ed.; CRC Press: Boca Raton, FL, USA, 1997; pp. 19-35.

22. Friedman, M.; Dao, L. Distribution of glycoalkaloids in potato plants and commercial potato products. J. Agric. Food Chem. 1992, 40, 419-442. [CrossRef]

23. Bajaj, K.L.; Kaur, G.; Chadha, M.L. Glycoalkaloid content and other chemical constituents of the fruits of some eggplant (Solanum melongena. L.) varieties. J. Plant Foods 1979, 3, 163-168. [CrossRef]

24. Tajner-Czopek, A.; Jarych-Szyszka, M.; Lisińska, G. Changes in glycoalkaloids content of potatoes destined for consumption. Food Chem. 2008, 106, 706-711. [CrossRef]

25. Fitzpatrick, T.J.; McDermott, J.A.; Osman, S.F. Evaluation of injured commercial potato samples for total glycoalkaloid content. J. Food Sci. 1978, 43, 1417-1418. [CrossRef]

26. Omayio, D.G.; Abong, G.O.; Okoth, M.W. A review of occurrence of glycoalkaloids in potato and potato products. Curr. Res. Nutr. Food Sci. 2016, 4, 195-202. [CrossRef]

27. Kalinowska, M.; Zimowski, J.; Paczkowski, C.; Wojciechowski, Z.A. The formation of sugar chains in triterpenoid saponins and glycoalkaloids. Phytochem. Rev. 2005, 4, 237-257. [CrossRef]

28. Roddick, J.G. Effect of $\alpha$-tomatine on the integrity and biochemical activities of isolated plant cell organelles. J. Exp. Bot. 1978, 29, 1371-1381. [CrossRef]

29. Friedman, M. Potato glycoalkaloids and metabolites: roles in the plant and in the diet. J. Agric. Food Chem. 2006, 54, 8655-8681. [CrossRef]

30. Tingey, W.M. Glycoalkaloids as pest resistance factors. Am. Potato J. 1984, 61, 157-167. [CrossRef]

31. Balandrin, M.F. Commercial Utilization of Plant-Derived Saponins: An Overview of Medicinal, Pharmaceutical, and Industrial Applications. In Saponins Used in Traditional and Modern Medicine. Advances in Experimental Medicine and Biology; Waller, G.R., Yamasaki, K., Eds.; Springer: Boston, MA, USA, 1996; Volume 404, pp. 1-14.

32. Ito, S.; Ihara, T.; Tamura, H.; Tanaka, S.; Ikeda, T.; Kajihara, H.; Dissanayake, C.; Abdel-Motaald, F.F.; El-Sayed, M.A. $\alpha$-Tomatine, the major saponin in tomato, induces programmed cell death mediated by reactive oxygen species in the fungal pathogen Fusarium oxysporum. FEBS Lett. 2007, 581, 3217-3222. [CrossRef] 
33. Sandrock, R.W.; Van Ette, H.D. Fungal sensitivity to and enzymatic degradation of the phytoanticipin $\alpha$-tomatine. FEBS Lett. 2007, 581, 3217-3222. [CrossRef]

34. Rubio, M.R.; Espinosa, A.P.; Lairini, K.; Arjona, T.R.; Dipietro, A.; Anaya, N. Metabolism of the tomato saponin $\alpha$-tomatine by phytopathogenic fungi. Stud. Nat. Prod. Chem. 2001, 25, 293-326.

35. Smith, D.B.; Roddick, J.G.; Jones, J.L. Synergism between the potato glycoalkaloids $\alpha$-chaconine and $\alpha$-solanine in inhibition of snail feeding. Phytochemistry 2001, 57, 229-234. [CrossRef]

36. Zhang, T.M.; Mitchell, B.K. Components of the tomato leaf homogenate suppress responses from Galeal chemoreceptors of the adult Colorado beetle. Physiol. Entomol. 1997, 22, 291-296. [CrossRef]

37. Friedman, M.; Kozukue, N.; Harden, L.A. Preparation and characterization of acid hydrolysis products of the tomato glycoalkaloid $\alpha$-tomatine. J. Agric. Food Chem. 1998, 46, 2096-2210. [CrossRef]

38. Mensinga, T.T.; Sips, A.J.A.M.; Rompelberg, C.J.M.; van Twillert, K.; Meulenbelt, J.; van den Top, H.; van Egmond, H.P. Potato glycoalkaloids and adverse effects in humans: An ascending dose study. Regul. Toxicol. Pharmacol. 2005, 41, 66-72. [CrossRef]

39. Morris, S.C.; Lee, T.H. The toxicity and teratogenicity of Solanaceae glycoalkaloids, particularly those of the potato (Solanum tuberosum): A review. Food Technol. Aust. 1984, 36, 118-124.

40. Roddick, J.G.; Rijnenberg, A.L.; Osman, S.F. Synergistic interaction between potato glycoalkaloids $\alpha$-solanine and $\alpha$-chaconine in relation to destabilization of cell membranes: Ecological implications. J. Chem. Ecol. 1988, 14, 889-902. [CrossRef]

41. Yamashoji, S.; Matsuda, T. Synergistic cytotoxicity induced by $\alpha$-solanine and $\alpha$-chaconine. Food Chem. 2013, 141, 669-674. [CrossRef]

42. Roddick, J.G.; Rijnenberg, A.L.; Weissenberg, M. Membrane-disrupting properties of the steroidal glycoalkaloids solasonine and solamargine. Phytochemistry 1990, 29, 1513-1518. [CrossRef]

43. Roddick, J.G. Complex formation between solanaceous steroidal glycoalkaloids and free sterols in vitro. Phytochemistry 1979, 18, 1467-1470. [CrossRef]

44. Elias, P.M.; Friend, D.S.; Goerke, J. Membrane sterol heterogeneity: Freeze fracture detection with saponins and filipin. J. Histochem. Cytochem. 1979, 27, 1247-1260. [CrossRef]

45. Koehler, J.K.; Clark, J.M.; Smith, D. Freeze-fracture observations on mammalian oocytes. Dev. Dynam. 1985, 174, 317-329. [CrossRef]

46. Francis, G.; Kerem, Z.; Makkar, H.P.S.; Becker, K. The biological action of saponins in animal systems: A review. Br. J. Nutr. 2002, 88, 587-605. [CrossRef]

47. Beknke, O.; Tranum-Jensen, J.; van Deurs, B. Filipin as a cholesterol probe. I. Morphology of filipin-cholesterol interaction in lipid model systems. Eur. J. Cell Biol. 1984, 35, 189-199.

48. De Groot, C.; Müller-Goymann, C.C. Saponin interactions with model membrane systems - Langmuir monolayer studies, hemolysis and formation of ISCOMs. Planta Med. 2016, 82, 1496-1512. [CrossRef]

49. Yang, S.-A.; Paek, S.-H.; Kozukue, N.; Lee, K.R.; Kim, J.-A. $\alpha$-Chaconine, a potato glycoalkaloid, induces apoptosis of HT-29 human colon cancer cells through caspase-3 activation and inhibition of ERK1/2 phosphorylation. Food Chem. Toxicol. 2006, 44, 839-846. [CrossRef]

50. Kúdelová, J.; Seifrtová, M.; Suchá, L.; Tomšík, P.; Havelek, R.; Řezáčová, M. Alpha-tomatine activates cell cycle checkpoints in the absence of DNA damage in human leukemic MOLT-4 cells. J. Appl. Biomed. 2013, 11, 93-103. [CrossRef]

51. Shieh, J.-M.; Cheng, T.-W.; Shi, M.-D.; Wu, P.-F.; Chen, Y.; Ko, S.-C.; Shih, Y.-W. $\alpha$-Tomatine suppresses invasion and migration of human non-small cell lung cancer NCI-H460 cells through inactivating FAK/PI3K/Akt signaling pathway and reducing binding activity of NF-kB. Cell Biochem. Biophys. 2011, 60, 297-310. [CrossRef]

52. Friedman, M.; Levin, C.E.; Lee, S.-U.; Kim, H.-J.; Lee, I.-S.; Byun, J.-O.; Kozukue, N. Tomatine-containing green tomato extracts inhibit growth of human breast, colon, liver, and stomach cancer cells. J. Agric. Food Chem. 2009, 57, 5727-5733. [CrossRef]

53. Koleva, I.I.; van Beek, T.A.; Soffers, A.E.M.F.; Dusemund, B.; Rietjens, I.M.C.M. Alkaloids in the human food chain - Natural occurrence and possible adverse effects. Mol. Nutr. Food Res. 2012, 56, 30-52. [CrossRef]

54. Choi, S.H.; Ahn, J.-B.; Kozukue, N.; Kim, H.-J.; Nishitani, Y.; Zhang, L.; Mizuno, M.; Levin, C.E.; Friedman, M. Structure-activity relationships of $\alpha_{-}, \beta_{1^{-}}, \gamma_{-}$, and $\delta$-tomatine and tomatidine against human breast (MDA-MB-231), gastric (KATO-III), and prostate (PC3) cancer cells. J. Agric. Food Chem. 2012, 60, 3891-3899. [CrossRef] 
55. Friedman, M.; Lee, K.-R.; Kim, H.-J.; Lee, I.-S.; Kozukue, N. Anticarcinogenic effects of glycoalkaloids from potatoes against human cervical, liver, lymphoma, and stomach cancer cells. J. Agric. Food Chem. 2005, 53, 6162-6169. [CrossRef]

56. Nakamura, T.; Komori, C.; Lee, Y.-Y.; Hashimoto, F.; Yahara, S.; Nohara, T.; Ejima, A. Cytotoxic activities of Solanum steroidal glycosides. Biol. Pharm. Bull. 1996, 19, 564-566. [CrossRef]

57. Sucha, L.; Hroch, M.; Rezacova, R.; Rudolf, E.; Havelek, R.; Sispera, L.; Cmielova, J.; Kohlerova, R.; Bezrouk, A.; Tomsik, P. The cytotoxic effect of $\alpha$-tomatine in MCF-7 human adenocarcinoma breast cancer cells depends on its interaction with cholesterol in incubation media and does not involve apoptosis induction. Oncol. Rep. 2013, 30, 2593-2602. [CrossRef]

58. Lee, K.-R.; Kozukue, N.; Han, J.-S.; Park, J.-H.; Chang, E.-Y.; Baek, E.-J.; Chang, J.-S.; Friedman, M. Glycoalkaloids and metabolites inhibit the growth of human colon (HT29) and liver (HepG2) cancer cells. J. Agric. Food Chem. 2004, 52, 2832-2839. [CrossRef]

59. Wei, G.; Wang, J.; Du, Y. Total synthesis of solamargine. Bioorg. Med. Chem. Lett. 2011, 21, $2930-2933$. [CrossRef]

60. Li, N.; Cao, L.; Wang, Y.-R.; Tao, X.-Q.; Ding, G.; Wang, Z.-R.; Xiao, W. Induction of Solasonine on Apoptosis of Human Breast Cancer Bcap-37 Cells through Mitochondria-Mediated Pathway. Chin. Herb. Med. 2016, 8, 164-172. [CrossRef]

61. Lee, S.-T.; Wong, P.-F.; Cheah, S.-C.; Mustafa, M.R. Alpha-tomatine induces apoptosis and inhibits nuclear factor-kappa B activation on human prostatic adenocarcinoma PC-3 cells. PLoS ONE 2011, 6, e18915. [CrossRef]

62. Zuber, T.; Holm, D.; Byrne, P.; Ducreux, L.; Taylor, M.; Kaiseraand, M.; Stushnoff, C. Optimization of in vitro inhibition of HT-29 colon cancer cell cultures by Solanum tuberosum L. extracts. Food Funct. 2015, 6, 72-83. [CrossRef]

63. Munari, C.C.; de Oliveira, P.F.; Leandro, L.F.; Pimenta, L.M.; Ferreira, N.H.; Carvalho da Costa, J.; Bastos, J.K.; Tavares, D.C. In Vivo Assessment of Genotoxic, Antigenotoxic and Anticarcinogenic Activities of Solanum lycocarpum Fruits Glycoalkaloidic Extract. PLoS ONE 2014, 9, e111999. [CrossRef]

64. Wu, C.-H.; Liang, C.-H.; Shiu, L.-Y.; Chang, L.-C.; Lin, T.-S.; Lan, C.-C.E.; Tsai, J.-C.; Wong, T.-W.; Wei, K.-J.; Lin, Y.T.-K.; et al. Solanum incanum extract (SR-T100) induces human cutaneous squamous cell carcinoma apoptosis through modulating tumor necrosis factor receptor signaling pathway. J. Dermatol. Sci. 2011, 63, 83-92. [CrossRef]

65. Kim, S.P.; Nam, S.H.; Friedman, M. The Tomato Glycoalkaloid $\alpha$-Tomatine Induces Caspase-Independent Cell Death in Mouse Colon Cancer CT-26 Cells and Transplanted Tumors in Mice. J. Agric. Food Chem. 2015, 63, 1142-1150. [CrossRef]

66. Rajananthanan, P.; Attard, G.S.; Sheikh, N.A.; Morrow, W.J.W. Novel aggregate structure adjuvants modulate lymphocyte proliferation and Th1 and Th2 cytokine profiles in ovalbumin immunized mice. Vaccine 1999, 18, 140-152. [CrossRef]

67. Sheikh, N.A.; Rajananthanan, P.; Attard, G.S.; Morrow, W.J.W. Generation of antigen specific CD8+ cytotoxic $\mathrm{T}$ cells following immunization with soluble protein formulated with novel glycoside adjuvants. Vaccine 1999, 17, 2974-2982. [CrossRef]

68. Chen, Y.; Li, S.; Sun, F.; Han, H.; Zhang, X.; Fan, Y.; Tai, G.; Zhou, Y. In-vivo antimalarial activities of glycoalkaloids isolated from Solanaceae plants. Pharm. Biol. 2010, 48, 1018-1024. [CrossRef]

69. Yang, Y.-W.; Sheikh, N.A.; Morrow, W.J.W. The ultrastructure of tomatine adjuvant. Biomaterials 2002, 23, 4677-4686. [CrossRef]

70. Yang, Y.-W.; Wua, C.-A.; Morrow, W.J.W. The apoptotic and necrotic effects of tomatine adjuvant. Vaccine 2004, 22, 2316-2327. [CrossRef]

71. Roddick, J.G.; Drysdale, R.B. Destabilization of liposome membranes by the steroidal glycoalkaloid $\alpha$-tomatine. Phytochemistry 1984, 23, 543-547. [CrossRef]

72. Roddick, J.G.; Rijnenberg, A.L.; Weissenberg, M. Alterations to the permeability of liposome membranes by the solasodine-based glycoalkaloids solasonine and solamargine. Phytochemistry 1992, 31, 1951-1954. [CrossRef]

73. Roddick, J.G.; Rijnenberg, A.L. Synergistic interaction between the potato glycoalkaloids $\alpha$-solanine and $\alpha$-chaconine in relation to lysis of phospholipid/sterol liposomes. Phytochemistry 1987, 26, 1325-1328. [CrossRef] 
74. Roddick, J.G.; Weissenberg, M.; Leonard, A.L. Membrane disruption and enzyme inhibition by naturally-occurring and modified chacotriose-containing Solanum steroidal glycoalkaloids. Phytochemistry 2001, 56, 603-610. [CrossRef]

75. Keukens, E.A.J.; de Vrije, T.; Fabrie, C.H.J.P.; Demel, R.A.; Jongen, W.M.F.; de Kruijff, B. Dual specificity of sterol-mediated glycoalkaloid induced membrane disruption. Biochim. Biophys. Acta 1992, 1110, 127-136. [CrossRef]

76. Keukens, E.A.J.; de Vrije, T.; van den Boom, C.; de Waard, P.; Plasman, H.H.; Thiel, F.; Chupin, V.; Jongen, W.M.F.; de Kruijff, B. Molecular basis of glycoalkaloid induced membrane disruption. Biochim. Biophys. Acta 1995, 1240, 216-228. [CrossRef]

77. Keukens, E.A.J.; de Vrije, T.; Jansen, A.M.; de Boer, H.; Janssen, M.; de Kroon, A.I.P.M.; Jongen, W.M.F.; de Kruijff, B. Glycoalkaloids selectively permeabilize cholesterol containing biomembranes. Biochim. Biophys. Acta 1996, 1279, 243-250. [CrossRef]

78. Giner-Casaresa, J.J.; Brezesinski, G.; Möhwald, H. Langmuir monolayers as unique physical models. Curr. Opin. Colloid Interface Sci. 2014, 19, 176-182. [CrossRef]

79. Stine, K.J.; Hercules, R.K.; Duff, J.D.; Walker, B.W. Interaction of the glycoalkaloid tomatine with DMPC and sterol monolayers studied by surface pressure measurements and Brewster angle microscopy. J. Phys. Chem. B 2006, 110, 22220-22229. [CrossRef]

80. Stine, K.J. Brewster Angle Microscopy. In Supramolecular Chemistry: From Molecules to Nanomaterials; Steed, J.W., Gale, P.A., Eds.; John Wiley \& Sons Ltd.: Chichester, UK, 2012; pp. 589-618.

81. Nandi, N.; Vollhardt, D. Effect of Molecular Chirality on the Morphology of Biomimetic Langmuir Monolayers. Chem. Rev. 2003, 103, 4033-4076. [CrossRef]

82. Walker, B.W.; Manhanke, N.; Stine, K.J. Comparison of the interaction of tomatine with mixed monolayers containing phospholipid, egg sphingomyelin, and sterols. Biochim. Biophys. Acta 2008, 1778, 2244-2257. [CrossRef]

83. Wojciechowski, K.; Orczyk, M.; Gutberlet, T.; Brezesinski, G.; Geue, T.; Fontaine, P. On the interaction between digitonin and cholesterol in Langmuir monolayers. Langmuir 2016, 32, 9064-9073. [CrossRef]

84. Orczyk, M.; Wojciechowski, K.; Brezesinski, G. Disordering effects of digitonin on phospholipid monolayers. Langmuir 2017, 33, 3871-3881. [CrossRef]

85. Orczyk, M.; Wojciechowski, K. Unusual penetration of phospholipid mono- and bilayers by Quillaja bark saponin biosurfactant. Biochim. Biophys. Acta 2014, 1838, 1931-1940.

86. Wojciechowski, K.; Orczyk, M.; Gutberlet, T.; Geue, T. Complexation of phospholipids and cholesterol by triterpenic saponins in bulk and in monolayers. Biochim. Biophys. Acta 2016, 1858, 363-373. [CrossRef]

87. Frenkel, N.; Makky, A.; Sudji, I.R.; Wink, M.; Tanaka, M. Mechanistic investigation of interactions between steroidal saponin digitonin and cell membrane models. J. Phys. Chem. B 2014, 118, 14632-14639. [CrossRef] 